\title{
Una placa de metal y un tejido de algodón: implicancias en relación a procesos locales, incaicos y coloniales en la llanura de Santiago del Estero (Argentina)
}

\section{A metal plate and a cotton fabric: implications in relation to local, Inca and colonial processes in the Santiago del Estero plain (Argentina)}

Constanza Taboada ${ }^{1}$, Sara M. L. López Campeny ${ }^{2}$ y Carlos I. Angiorama ${ }^{3}$

\section{Resumen}

Este artículo parte del análisis de dos objetos arqueológicos de colección, para abordar cuestionamientos claves en la comprensión de los procesos sociohistóricos de las poblaciones indígenas que habitaron la llanura de Santiago del Estero durante el período Prehispánico Tardío y Colonial temprano. Estas cuestiones se refieren al manejo textil y a las fibras usadas por poblaciones que tuvieron gran desarrollo de la hilandería, y al papel de los objetos de metal en una región carente de tradición metalúrgica. Para ello realizamos el análisis tecnomorfológico y una datación del primer fragmento textil posible de ser sometido a estudio, así como la determinación de composición por DRX y análisis de manufactura de una placa circular de metal a la que se encontraba adherido el tejido. Se integra, a su vez, información procedente de pseudomorfos textiles registrados sobre piezas metálicas halladas en la región y otras evidencias y datos vinculados al tema, derivados del estudio de colecciones, excavaciones propias, bibliografía regional y fuentes históricas coloniales. Este corpus de información es puesto en perspectiva en relación al contexto sociocultural regional para abordar la discusión no solo de procesos locales sino también de eventos macrorregionales, tales como el avance incaico y la conquista española.

Palabras claves: tierras bajas, Santiago del Estero, inca, colonial, atuendo.

\begin{abstract}
This paper starts from the analysis of two archaeological objects to approach key questions in the understanding of socio-historical processes of indigenous populations that inhabited the Santiago del Estero plain, during Late Prehispanic and Early Colonial periods. These issues refer to the management of textiles and fibers used by populations which had a great development of spinning, and to the role of metal objects in a region lacking a metallurgical tradition. For this we perform the techno-morphological analysis and the date of the first textile fragment capable of being studied, as well as the determination of the composition by X-ray diffraction and manufacture analysis of a circular metal plate to which the textile was adhered. We also integrate information from textile pseudomorphs registered in metallic objects found in the region and other evidence and data related to the subject and derived from the study of collections, our own excavations, regional literature and historical sources from the colonial period. This information corpus is put into perspective in relation to the regional socio-cultural context to approach the discussion not only of local processes but also of macro-regional events such as the incaic advance and the hispanic conquest.
\end{abstract}

Keywords: low lands, Santiago del Estero, inca, colonial, dress.

Recibido: 4 agosto 2016. Aceptado: 25 noviembre 2016

1 Instituto Superior de Estudios Sociales (CONICET) / Instituto de Arqueología y Museo (Universidad Nacional de Tucumán), San Martín 1545, CP 4000, San Miguel de Tucumán, ARGENTINA. Email: constanzataboada@gmail.com

2 Instituto Superior de Estudios Sociales (CONICET) / Instituto de Arqueología y Museo (Universidad Nacional de Tucumán), San Martín 1545, CP 4000, San Miguel de Tucumán, ARGENTINA. Email: marisalopezc@hotmail.com

3 Instituto Superior de Estudios Sociales (CONICET) / Instituto de Arqueología y Museo (Universidad Nacional de Tucumán), San Martín 1545, CP 4000, San Miguel de Tucumán, ARGENTINA. Email: carlosangiorama@gmail.com 


\section{Introducción}

Este artículo parte del análisis de dos objetos arqueológicos de colección para abordar cuestionamientos claves en la comprensión de los procesos sociohistóricos de las poblaciones indígenas que habitaron la llanura de Santiago del Estero (tierras bajas de Argentina) durante el período Prehispánico Tardío y Colonial temprano. Estos objetos son una placa circular de metal y un fragmento de textil de algodón que se encontraba adherido a la parte posterior de la placa. El conjunto constituye una situación excepcional en relación al registro que se conserva en la zona, e integra las colecciones del Museo de Ciencias Antropológicas y Naturales Emilio y Duncan Wagner, de Santiago del Estero (en adelante MCAEDW). Las cuestiones a las que apuntamos se refieren, por un lado, a la determinación de las fibras textiles y modos de hacer puestos en práctica por poblaciones locales que confeccionaron miles de husos de hilar ${ }^{4}$ recuperados por la arqueología local, pero de cuya textilería hoy solo se cuenta con el fragmento analizado en este trabajo. Nuestras preguntas se relacionan, por su parte, con otra indagación que también venimos realizando hace un tiempo, referida al papel que jugaron más de 150 objetos de metal (muchos de ellos de raigambre incaica) hallados en una región carente de tradición metalúrgica prehispánica como es la llanura santiagueña y clásicamente excluida de la zona de impacto incaico en el Noroeste Argentino (en adelante NOA).

En función de ir despejando diversas dudas relacionadas con estas problemáticas generadas a lo largo de la producción arqueológica e historiográfica local, se decidió realizar la datación del fragmento textil en cuestión, así como la determinación taxónomica de la fibra utilizada. A la vez se realizó el análisis de composición y tecnomorfólogico de éste y de la placa de metal a la que estaba adherido. También se rastreó la posible procedencia y contex-

4 Estos implementos son conocidos también en la región con el nombre genérico de "torteros" y en el quichua local son designados como muyunas. Otro término que suele estar asociado a estos ítems textiles es el de "fusaiolas", de uso más común en la bibliografía europea, pero que se popularizó en el área por la influencia de los trabajos arqueológicos pioneros de los hermanos Wagner, de origen francés. to de hallazgo. Se integran a la investigación, además, un primer análisis de pseudomorfos ${ }^{5}$ textiles registrados sobre piezas metálicas de la zona (Angiorama et al., 2018) y otras evidencias e información vinculadas al tema derivadas del estudio de colecciones, bibliografía regional, fuentes coloniales y excavaciones propias. Entre estas últimas se incluye otra situación excepcional, cual fue la identificación de hilados de algodón asociados a un tortero recuperado en un contexto de excavación controlado en el sitio Sequía Vieja (López Campeny y Taboada, 2016). Poniendo en diálogo todo ello, el artículo busca hacer un análisis crítico de lo conocido y planteado hasta ahora en relación a las cuestiones ya señaladas, abordando la discusión no solo de procesos locales, sino también de eventos macrorregionales, como el avance incaico y la conquista española.

El hecho de la asociación entre la placa y el textil aporta, evidentemente, un plus de potencialidad al análisis tecnomorfológico aislado de cada evidencia a la hora de abordar y afinar hipótesis y especulaciones derivadas, tanto de la ausencia de datos contextuales para los objetos de metal hallados en la zona como de la rareza de cada una de estas dos materialidades para el área (Angiorama y Taboada, 2008). Esta singularidad está dada por razones diferentes en cada situación. En el caso de la placa, por ser los objetos de metal ajenos a la región, siendo particularmente relevante su presencia en relación a una posible interacción y alianza de las poblaciones locales con el incario en una zona fuera del alcance tradicionalmente planteado para el Imperio (Angiorama y Taboada, 2008, 2016; Taboada, 2014; Taboada y Angiorama, 2010). Su asociación a la tela permite ampliar una serie de atributos en relación al papel de este objeto dentro del cuadro histórico local y regional, y el fechado posibilita afinarlo cronológicamente.

5 Si bien el término "pseudomorfo" se aplica de manera específica en el ámbito de la geología para referirse a la presencia de un mineral que se presenta bajo la forma cristalina de otro, nos parece adecuado mantener el término en este contexto, con idéntico sentido, aunque de una forma más genérica. Es decir que, con la expresión "pseudomorfo textil" nos referimos a la presencia de una sustancia no textil (mineral o no orgánica) que se manifiesta bajo la forma de una estructura textil (hoy ausente), aunque sin aludir por el momento a ningún proceso de formación específico. 


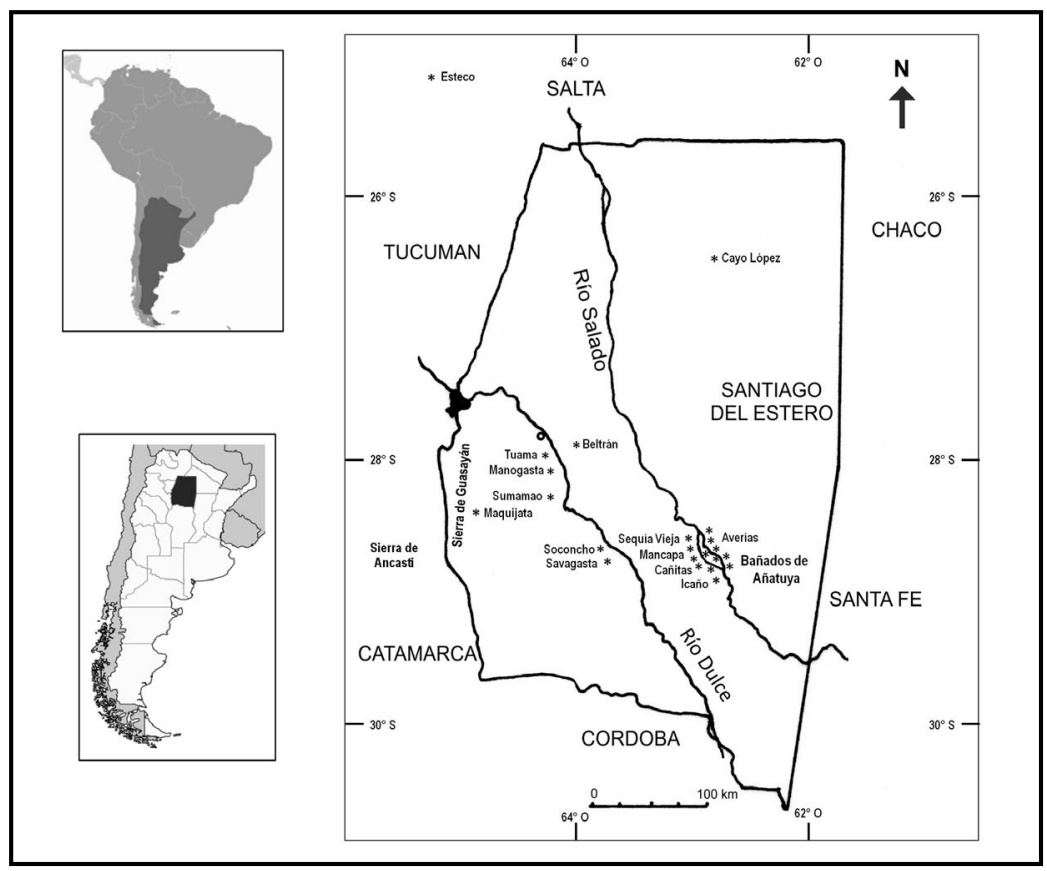

Figura 1. Mapa que señala la localización de los sitios arqueológicos, pueblos de indios y otras referencias geográficas de interés que son nombradas en el texto.

En el caso del textil, su recuperación es excepcional debido a que este hallazgo constituye el primer fragmento textil arqueológico cuya estructura pudo ser sometida a una serie de análisis contemporáneos, ya que hasta ahora solo se contaba con escasas referencias bibliográficas de otras evidencias textiles y sin datos sobre su conservación y/o paradero actual. Es posible entonces contar, por fin, con un indicador textil directo e integrarlo al estudio que sobre el tema venimos realizando a partir de indicadores indirectos en la región (López Campeny, 2011, 20112012, 2016; Taboada y López Campeny, 2009) y a preguntas que intentamos responder en nuestro proyecto, tales como: a) si existió un cultivo/uso prehispánico del algodón en la llanura santiagueña - discutido a partir de ciertas referencias de fuentes coloniales- y si hubo otras posibles fibras utilizadas (López Campeny y Taboada, 2016), b) si hubo un interés por este producto por parte del incario (Taboada y Angiorama, 2010; Taboada, Angiorama, Leiton y López Campeny, 2013), y c) sobre cuáles fueron las prácticas vinculadas al atuendo y el ajuar funerario dentro de la diversidad espacial, temporal y cultural regional (Angiorama y Taboada, 2016; Farberman y Taboada, 2012; Taboada et al., 2015;
Taboada y Farberman, 2014). El caso aquí presentado aporta tres situaciones únicas hasta el momento: una asociación directa de dos objetos raros en el registro arqueológico local, la datación absoluta de un textil y la posibilidad de determinar fehacientemente la fibra utilizada. Esto resulta valioso porque, hasta ahora, todos los objetos de metal de carácter incaico conocidos que fueron recuperados en la llanura santiagueña integran colecciones de museos y carecen de datos de asociación y contexto ${ }^{6} \mathrm{y}$, como ya enfatizamos, porque no contábamos, hasta el momento y para el área, con evidencias textiles directas posibles de ser analizadas en el presente.

\section{Problemática}

El conjunto compuesto por la asociación de la placa con el textil procede -en principio, y ampliaremos luego- de la provincia de Santiago del Estero, en las tierras bajas de la República Argentina (Figura 1).

6 Casi todos los objetos metálicos recuperados en la región presentan la misma limitación. Son la excepción unos poquísimos ejemplares recuperados en excavaciones modernas, pero justamente esos no presentan características incaicas. 
La zona integra la ecorregión del Chaco Seco, con clima subtropical continental, y se caracteriza por tener temperaturas extremas y precipitaciones abundantes en el verano. La provincia está cruzada por dos ríos principales de gran caudal, el Dulce y el Salado. Salvo las sierras bajas ubicadas al oeste y sur, que presentan recursos y características ambientales diferentes, el resto de la provincia queda incluida en la Llanura Chaqueńa y presenta un relieve llano con un promedio de altitud de $230 \mathrm{msnm}$. La provincia incluye parte de las tierras bajas de Argentina más próximas al piedemonte andino. Esta situación se ve reflejada en múltiples procesos históricos que parecen mostrar una interacción activa de sus pobladores con los de las zonas vecinas, los Andes y el Chaco, en distintos momentos de su historia (Farberman y Taboada, 2012; Gómez, 1970, 1975; Gramajo y Martínez Moreno, 1992; Lorandi, 1978, 2015; Taboada, 2011, 2014; Taboada et al., 2013; Taboada y Farberman, 2014; Togo, 2004; entre otros).

Dentro de esta amplia llanura, los estudios de campo de nuestro proyecto se concentran en una zona particular del río Salado conocida como "Bańados de Añatuya”, con énfasis en los sitios Sequía Vieja y Mancapa. Esta área presenta recursos y posibilidades de vida, de explotación, de producción y de interacción aparentemente más variadas que otros sectores de la provincia estudiados hasta ahora (Angiorama y Taboada, 2016; Palomeque, 1992). Entre otras particularidades, en esta zona se concentra casi la totalidad de los objetos arqueológicos de metal hallados en la provincia (más de 150) y poco más de unos 8 mil torteros o contrapesos para hilar ${ }^{7}$ (Figura 2). En función de estos y otros indicadores hemos propuesto que este espacio constituyó un territorio prehispánico diferenciado por sus recursos naturales y por las habilidades técnicas y políticas de negociación de sus pobladores, posiblemente fuente del interés manifestado por la zona tanto por el incario como por la Colonia (Angiorama y Taboada, 2016; Taboada, 2014; Taboada y Farberman, 2014).

7 Estos datos provienen del relevamiento de las colecciones del MCAEDW hoy depositadas en el Centro de Interpretación y Conservación del Patrimonio Cultural de Santiago del Estero (CICPSE) y de la información publicada en la literatura arqueológica.
A pesar de la gran cantidad de objetos de metal hallados, la zona de estudio no cuenta con fuentes de minerales metalíferos, estando las más próximas a unos $400 \mathrm{~km}$ de distancia hacia el oeste. Tampoco se registra en el lugar una tradición metalúrgica local, ni evidencias de manufactura de objetos metálicos. La composición de las piezas halladas en la región y analizadas es, en general, bronce estañífero y plata, y hay una única referencia a un objeto de oro, hoy aparentemente perdido (Pedersen, 1952; Wagner y Righetti, 1946). Gran parte de los materiales son objetos terminados que responden a patrones incaicos o valliserranos del NOA. Se trata en su mayoría de piezas de prestigio y/o asociadas a indumentaria, tanto masculina como femenina (p.e. brazaletes, topus, lauraques), aunque hay también algunas de carácter utilitario (cinceles y punzones) (ver Figura 2). Lamentablemente, la mayoría de ellas fueron recuperadas en excavaciones de índole coleccionista, realizadas hasta mediados del siglo XX por los hermanos Wagner (Wagner y Wagner, 1934) y por Pedersen (1952) y carecen de datos contextuales (Angiorama y Taboada, 2008; Martínez, Taboada y Auat, 2011). Un primer estudio específico que realizamos sobre los objetos de metal de la zona concluyó que es factible que, al menos algunas de ellas, hayan llegado a los Bañados de Añatuya como dones en el marco de alianzas con el Imperio incaico (Angiorama y Taboada, 2008). Nuevos estudios permiten pensar en el rol activo que pudieron desempeñar estas piezas en el marco de la interacción entablada entre las poblaciones locales y el Imperio, como atuendo de funcionarios incas o invistiendo a jefes locales y mujeres destacadas, mientras que los objetos más utilitarios, por su parte, podrían vincularse a un posible centro de manufactura de artefactos de hueso (Angiorama y Taboada, 2016). También hemos considerado que estos bienes pudieron seguir actuando en la vida cotidiana y a la hora de la muerte en época colonial (Taboada, 2014).

Por otra parte, a pesar de que diversos indicadores -especialmente torteros para hilados, pero también artefactos vinculados quizás a almacenar las hebras y otros para tejer, coser y/o terminar las prendas (López Campeny, 2011-2012, 2016; Reichlen, 1940; Righetti, 1942; Rusconi, 1933; Wagner y Wagner, 1934) - evidencian la práctica local del hilado y el tejido, son muy escasas las referencias sobre piezas 


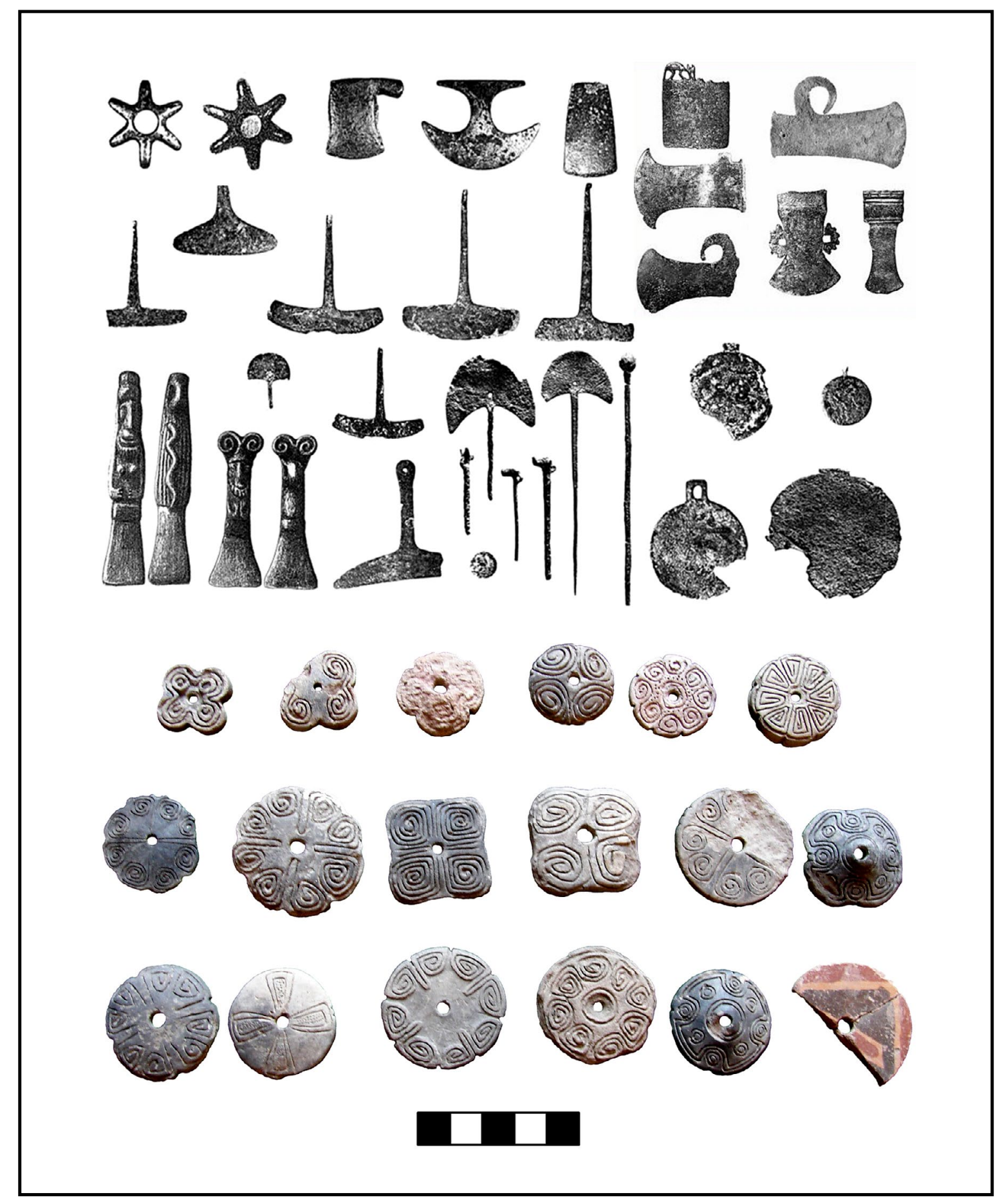

Figura 2. Algunas piezas de metal y pesos de hilado (torteros) hallados en elevadas cantidades en los sitios del Salado, región de Bañados de Añatuya, Santiago del Estero. Imagen superior: Gráficos tomados de Mayer, 1986; Pedersen, 1952; Reichlen, 1940 y Wagner \& Righetti, 1948. No se incluye escala de referencia para los objetos ilustrados debido a que en las publicaciones originales no constan sus tamaños. Imagen inferior: Torteros arqueológicos procedentes de sitios de Santiago del Estero pertenecientes a la colección del Museo Antropológico E. y D. Wagner de la provincia de Santiago del Estero. Actualmente albergados en el Centro de Interpretación y Conservación del Patrimonio Cultural de Santiago del Estero (CICPSE). 
textiles arqueológicas halladas en Santiago del Estero. Esto se debe principalmente a las condiciones ambientales imperantes en el área, que no favorecen la conservación de los restos orgánicos. Para los casos preservados solo contamos con algunas menciones breves que carecen de datos acerca de la determinación taxonómica de las fibras textiles y de especificaciones técnicas sobre las estructuras, fotografías y/o gráficos detallados de las piezas en cuestión. ${ }^{8} \mathrm{~A}$ estas menciones se agregan, en ocasiones, apreciaciones generales y subjetivas acerca de la calidad técnica y/o estética de las piezas. Pero en ningún caso ha sido posible confrontar las observaciones vertidas originalmente o profundizar en el conocimiento de las piezas con la realización de nuevos análisis, ya que no se han hallado datos sobre el paradero actual de las telas en cuestión o, incluso, información acerca de si las mismas se conservaron hasta el presente. En consecuencia, una de las incógnitas sobre el tejido de la región es cuál o cuáles fueron las materias primas utilizadas en tiempos prehispánicos en Santiago del Estero. A partir de los pocos fragmentos textiles referidos, se ha realizado una asignación apriorística sobre el uso de "fibra vegetal (¿algodón?) [190]" (d'Harcourt, 1932) y "probablemente de lana de guanaco [182]" (Reichlen, 1940) pero no había, hasta ahora, determinaciones fehacientes y sí controversias al respecto derivadas en su mayoría de referencias coloniales. Este último autor se refiere además a "una araña, que vive en colonias y cuya seda se recogió y se usó para tejer [143]".

8 La sola excepción parcial a esta situación la constituye el trabajo de R. d'Harcourt (1932), que proporciona la única referencia técnica precisa con la que contábamos hasta el presente, para una pieza textil recuperada en contextos arqueológicos del área. Más adelante profundizamos sobre este hallazgo.

9 Si bien existen otras menciones sobre el posible uso -con fines textiles- de una seda segregada por una araña local, incluso por parte de cronistas coloniales (cfr. Corcuera, 2006), no hay ningún dato concreto que, hasta ahora, confirme tal posibilidad en el pasado prehispánico. De lo que sí existen datos concisos es de la presencia de una especie de mariposa nocturna (Rothschildia maurus) que vive en los montes espinosos del centro-oeste de Argentina y se conoce en los montes de Santiago del Estero y Catamarca con el nombre vulgar de coyuyo, punucha, pulucha, entre otros. La oruga de este lepidóptero produce un capullo ("bolsita") que se recolecta y se somete a un proceso particular para obtener la fibra de la llamada localmente "seda salvaje o del monte", con la que se ela-
La dificultad de preservación natural de la evidencia textil en el área llevó a concentrar nuestros estudios acerca de su producción en el análisis de una serie de indicadores indirectos de esta actividad, tales como improntas conservadas en superficies cerámicas y un conjunto diverso de instrumental productivo textil (López Campeny, 2010, 2011, 2011-2012, 2016; Taboada et al., 2013). Se estudió un elevado número de torteros recuperados en varios sitios de Santiago del Estero. La búsqueda se encaminó a la sistematización de información dispersa (arqueológica, etnográfica, histórica y actual) que nos permitiera proponer un conjunto de atributos tecnológicos - presentes en los pesos de hilar- que pudieran ser útiles como referentes o indicadores indirectos del procesamiento de distintas materias primas y/o atributos de los productos obtenidos, es decir, los hilados (López Campeny 2011-2012). Este estudio se complementó con la realización de ensayos experimentales de resistencia mecánica a la tensióntracción, para fibras arqueológicas de diferente naturaleza y con distintos atributos tecnológicos de construcción (López Campeny et al., 2017; Romano y López Campeny 2015). ${ }^{10}$ Basados en el primer conjunto de indicadores tecnológicos que pudimos inferir, y en el estudio de estos atributos y variables en un conjunto acotado de la muestra de pesos arqueológicos, concluimos que una proporción mayoritaria de los torteros estudiados coincidía con las características técnicas (peso y dimensiones) relevadas para torteros empleados en el hilado de fibras de algodón para referentes etnográficos y arqueológicos de otras áreas (López Campeny 2011-2012). Como veremos, hay conocimiento fehaciente de que esta materia prima fue efectivamente hilada y tejida en nuestra región, al menos durante la Colonia temprana, aunque es incierto si se cultivó en ella tanto como su presencia prehispánica. Pudo también haber sido entregada como tributo al Inca por los pobladores locales, según parecen indicar ciertas fuentes que expondremos luego. Sin embargo, hasta

boran diversos tejidos en la actualidad e incluso se conocen prendas históricas (siglo XIX) elaboradas con esta materia prima (Corcuera, 2006; Kriscautzky y Gómez, 1984; Ledesma, 1961).

10 Los ensayos fueron realizados -en el marco del PICT 2011/N²41- por el prof. Gustavo V. Guinea, en el Departamento de Ciencia de Materiales de la Universidad Politécnica de Madrid, España. 
hace poco, solo contábamos con torteros que procedían de colecciones museográficas, lo que introducía el problema de la falta de datos de asociación y condiciones de hallazgo que permitieran afinar cronologías y contextos de uso.

En lo que respecta, entonces, a la cronología de los torteros hallados en el área de estudio, hay unos cuantos registros de estos implementos en contextos claramente prehispánicos (Lorandi, 2015), pero las grandes cantidades de estas piezas que señalamos más arriba fueron recuperadas por una arqueología coleccionista, sin datos contextuales, en sitios con ocupación prehispánica tardía y colonial. Esto impide asignar con certeza tales magnitudes de pesos de hilar a uno u otro momento, o a ambos. El gran desarrollo de la actividad textil durante la Colonia en la región (Castro Olañeta, 2013a; Farberman y Boixados, 2006; Ferreiro, 1997; Palomeque, 2005), sobre el que luego nos extenderemos, nos hace pensar en que parte de estos implementos podrían remitir a ese intenso proceso. Sin embargo, nada impide hasta ahora que -una o la mayor parte de ellos- puedan ser prehispánicos. De hecho, la actividad textil puede ubicarse con seguridad para la zona central de Santiago del Estero desde alrededor del 1200 DC, ${ }^{11}$ incrementándose luego notablemente (Lorandi 2015). Se ha planteado que este auge textil tardío pudo estar ligado a interacciones prehispánicas con pueblos del oriente y altiplano sur de la actual Bolivia (Lorandi, 1978, 2015). Por nuestra parte, hemos señalado que el vínculo entablado con el incario también pudo ser el motivo de un incremento prehispánico tardío en el desarrollo de la textilería local, y que la Colonia más bien habría aprovechado luego esta circunstancia y reorganizado la actividad (Angiorama y Taboada, 2016; Taboada y Angiorama, 2010). En este sentido, las grandes magnitudes de torteros se han registrado, hasta ahora, justamente en sitios con evidencias incaicas que luego fueron ocupados durante la Colonia. Hemos pensado así en una habilidad y tradición local que pudo haber despertado el interés del incario. Uno de los motivos de este interés pudo ser, además, el

11 La estimación se basa en un promedio de la calibración actual de los fechados radiocarbónicos obtenidos por Lorandi (1978) para los contextos de la fase Quimilí Paso, que es la primera en la que registra torteros. Sin embargo, un fechado cubre un rango bastante más antiguo. algodón, considerando las condiciones ambientales locales, sumamente aptas para su cultivo y otros factores que argumentaremos luego. En este marco, los incas bien pudieron intervenir en la organización, incrementando la escala de la producción. En esta hipótesis, al menos parte de estas grandes cantidades de torteros podrían vincularse al proceso incaico y a momentos prehispánicos tardíos en tanto piezas muy similares a las del área de estudio han sido halladas en sitios incaicos del NOA, entre otras evidencias analizadas en diversos trabajos (Taboada $\mathrm{y}$ Angiorama, 2010; Taboada et al., 2013, etc.). ${ }^{12}$

\section{Descripción técnica y análisis del material de estudio}

\section{La placa de metal}

En el contexto de la problemática local, esta placa es uno de los varios casos de objetos de metal de origen foráneo hallados en Santiago del Estero, cuya presencia en la llanura santiagueña ha sido planteada anteriormente en relación a la problemática inca.

La placa lleva inscripto con tinta el número de registro 1888 en una de sus caras. Se trata de una pieza de contorno circular, plana y presenta dos agujeros circulares para sujeción, próximos entre sí, junto al borde (Figura 3). Ha sido fabricada por vaciado de metal en un molde. Los orificios de sujeción han sido perforados luego de la solidificación del objeto, y sugieren que habrían sido utilizados para coser la placa a un soporte textil. Se encuentra cubierta por completo por una capa de corrosión que es producto de la meteorización del metal original, proceso que ha afectado especialmente los bordes de la pie$\mathrm{za}$, que ha perdido su contorno circular original. Al objeto le falta una pequeña porción del borde, de forma irregular, extraída mediante una herramienta cortante en tiempos muy recientes.

12 En el mismo sentido, la comparación de producción de lienzos de algodón por india entre Maquijata, en Santiago del Estero, y otras zonas, podría considerarse, según Ferreiro (1997), como un parámetro que revela cierta experticia de tradición prehispánica por parte de las indias de Santiago del Estero. 


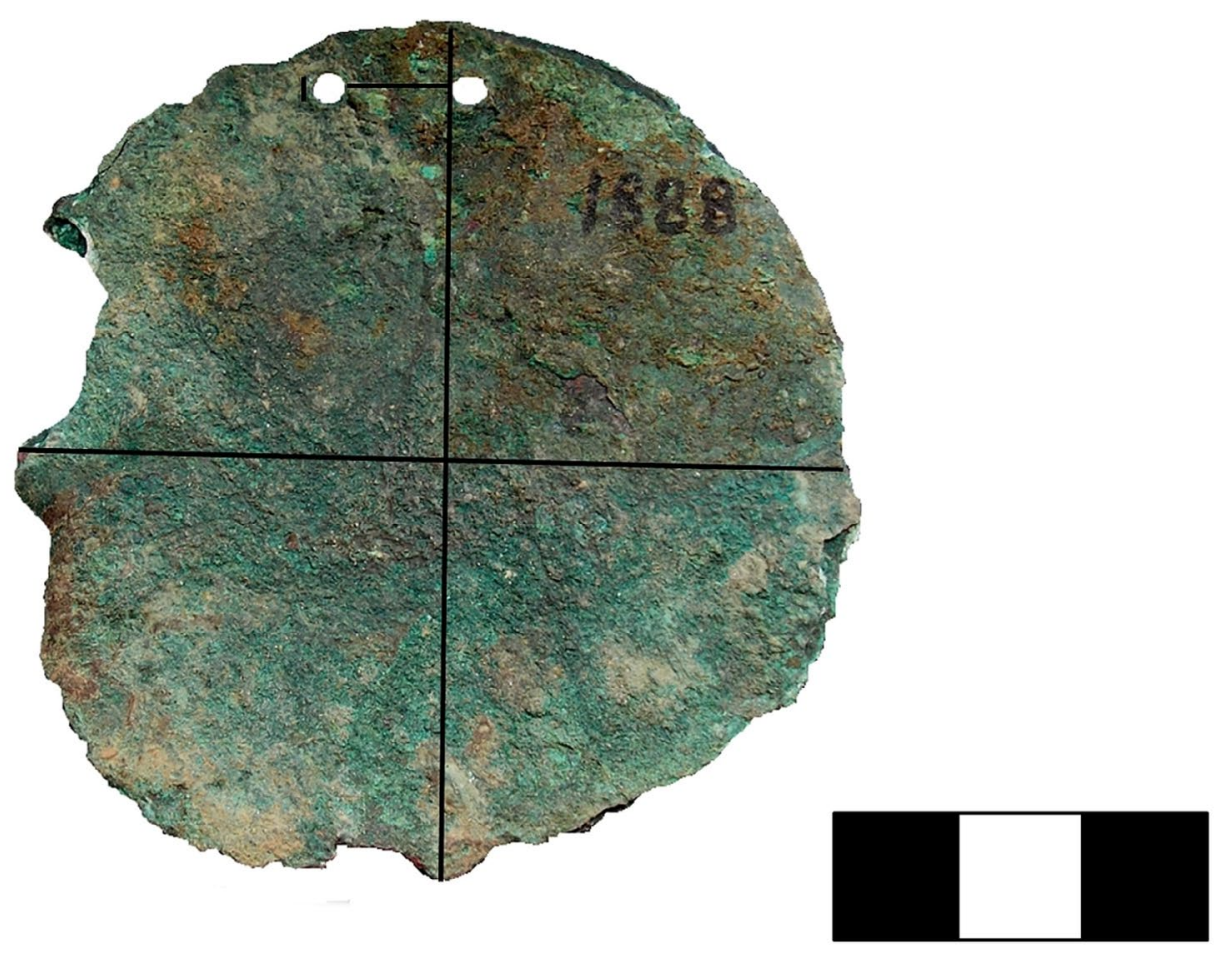

Figura 3. Placa circular de bronce analizada en el presente trabajo. La localización de las mediciones se indica en la fotografía. Largo máximo: $70 \mathrm{~mm}$; ancho máximo: $68 \mathrm{~mm}$; diámetro de los orificios: izquierdo $2 \mathrm{~mm}$ y derecho $2,2 \mathrm{~mm}$ y distancia entre los orificios: $13 \mathrm{~mm}$. Espesor: 2,5 $\mathrm{mm}$ y peso: $22,5 \mathrm{~g}$.

Para conocer su composición hemos realizado análisis mediante Dispersión de Energía de Rayos X (EDAX).$^{13}$ Se removió mecánicamente la pátina de ciertos microsectores de la pieza, y allí se tomaron cuatro mediciones. Luego se realizaron determinaciones en diversas porciones de la pátina superficial para lograr un control eficaz de los resultados. El EDAX es una técnica que detecta en la muestra analizada todos los elementos de peso atómico mayor a once y que se encuentren en concentraciones de alrededor de un $0,5 \%$ o más. El error analítico se estima en un $2 \%$.

De acuerdo con las mediciones obtenidas, la composición promedio del metal original de la placa es la siguiente: $\mathrm{Cu}: 87,68 \%$, Sn: $9,73 \%$ y S: $2,59 \%$. Estos datos significan que la placa fue confeccionada con una aleación de bronce estañífero, con una

13 Para los análisis EDAX se empleó un equipo Philips PSEM 500 acoplado a un Microscopio Electrónico de Barrido (MEB). proporción de estaño que se ubica dentro del rango normal para el Noroeste Argentino prehispánico. La presencia de azufre como impureza sugiere que el cobre ha sido obtenido a partir de la fundición de algún sulfuro. La composición de la placa, bronce estañífero, resulta similar a la de 27 de los 29 objetos hallados en al área de estudio analizados por Pedersen (1952). De las dos piezas restantes, una también presenta estaño pero en muy baja proporción, mientras que la otra fue confeccionada con cobre puro. A diferencia de nuestro caso, solamente dos de los objetos analizados por Pedersen presentan trazas de azufre, pero esto puede deberse a la resolución de la técnica de análisis empleada por el mencionado autor (la cual no consta en su publicación).

Por su parte, si bien en el NOA se han hallado numerosas piezas metálicas de morfología, tamaño y composición (cobre como metal base) semejantes a la que es objeto de este trabajo, las placas circulares que presentan dos orificios para sujeción cercanos al 
borde son relativamente escasas. Además de la presentada en este artículo, hemos hallado otras cinco publicadas. Una procede del sitio arqueológico de La Paya (Salta), otra de Villavil (Catamarca), otra de Santa Catalina (localidad de la puna de Jujuy, no hay datos acerca del lugar exacto de hallazgo), una de Cheaj ${ }^{14}$ (también llamado Cheej) (Santiago del Estero, departamento San Martín) y una de Sequía Vieja (Santiago del Estero) (González, 1992). O sea, de las seis placas de este tipo conocidas para el NOA, tres proceden de Santiago del Estero. Las halladas en La Paya y Villavil fueron encontradas en tumbas que se ha estimado datarían de época preincaica (González, 1992), mientras que para las demás no contamos con información acerca de los contextos de hallazgo. Además de las piezas mencionadas, se han hallado otras tres de morfología parecida y sistema de sujeción similar, pero confeccionadas en plata. Todas proceden de Pueblo Viejo de Rodeo Colorado, sitio de época incaica localizado en los valles orientales de Salta (Ventura y Scambato, 2013).

Las placas circulares, como la que nos ocupa en este trabajo, podrían asimilarse a las piezas interpretadas por Horta (2008) como tincurpas (H. Horta, com. pers. 2015). Según el estudio de la autora, este tipo de insignias eran llevadas en la frente por ciertos nobles incas, como un posible denotador de jerarquía y dualidad. No formarían parte de la vestimenta cotidiana, sino que habrían estado reservadas para fiestas o situaciones especiales. Horta (2008) señala, además, su asociación a "ídolos, 'bultos' de antepasados, nobles y estatuillas ofrendadas [85-86]", y su uso como emblema de los funcionarios del Estado en las provincias del Imperio, por los varones de la mitad de abajo (o Hurin), y por los casados con mujeres "de afuera" o ajenas al linaje real. La mayoría de los ejemplos analizados por Horta, sobre la base de las ilustraciones de Guaman Poma, muestra este tipo de placa cosida a un llautu o casco. El llautu era entregado como obsequio especial por el inca a la nobleza. La autora refiere el hallazgo de un ejemplar de este tipo de placa en una tumba que interpreta de élite (de un orejón), en un asentamiento de mitimaes localizado en un oasis

14 Podría ser parte de la colección Argañaraz, por tratarse de uno de los sitios excavados por este investigador. costero de los valles occidentales de Chile (Horta, 2008). Todo lo dicho resulta significativo de pensar en relación a nuestra hipótesis de interacción de poblaciones de Santiago del Estero con el incario, que contempla la posibilidad de que enviados del Inca llegaran a la zona o que se estuviera invistiendo a jefes locales, en base al análisis -entre otras evidencias- del tipo de objetos de metal hallados en la zona, entre los que justamente priman aquellos vinculados a investidura y vestimenta de hombres y mujeres destacados (Taboada, 2014; Angiorama y Taboada, 2016). Sin embargo, no podemos dejar de considerar que, si bien el tamaño, el material del que está compuesto y la forma circular de nuestro ejemplar son en efecto consistentes con la adscripción señalada, la pieza en estudio presenta dos orificios junto al borde, mientras que las consideradas por Horta poseen una única perforación central, que serviría para su sujeción al llautu o casco.

\section{El fragmento de textil}

El textil que nos ocupa consiste en un fragmento de forma aproximadamente rectangular y pequeñas dimensiones (Figura 4).

El reducido tamaño del fragmento (debido a una baja integridad), sumado a la ausencia de orillos (bordes) conservados y terminaciones o cualquier tipo de elemento no estructural (p.e. costuras) nos impide tanto conocer sus dimensiones originales como vincular la pieza con una determinada morfología (tipo de prenda o pieza) o función; por lo que solo puede describirse -de forma general- como un fragmento de tela. Su estudio tecnomorfológico se basó en la observación (macroscópica, a ojo desnudo y magnificada con empleo de lupa binocular estereoscópica a 40X) de la pieza textil en cuestión, con el fin de registrar una serie de atributos y variables, formales y técnicos, que consideramos relevantes para su caracterización y descripción (Tabla 1; cfr. López Campeny, 2000).

En términos de su estructura textil, la pieza corresponde a un tejido llano o plano (1/1) plain weave (D’Harcourt, 1962 [15]; Emery, 1966 [76]) de tipo no equilibrado o no balanceado, elaborado en faz de urdimbre, warp faced (Emery, 1966 [76]), o urdimbre vista Gisbert, Arce y Cajías 1987 [30]). Desde 


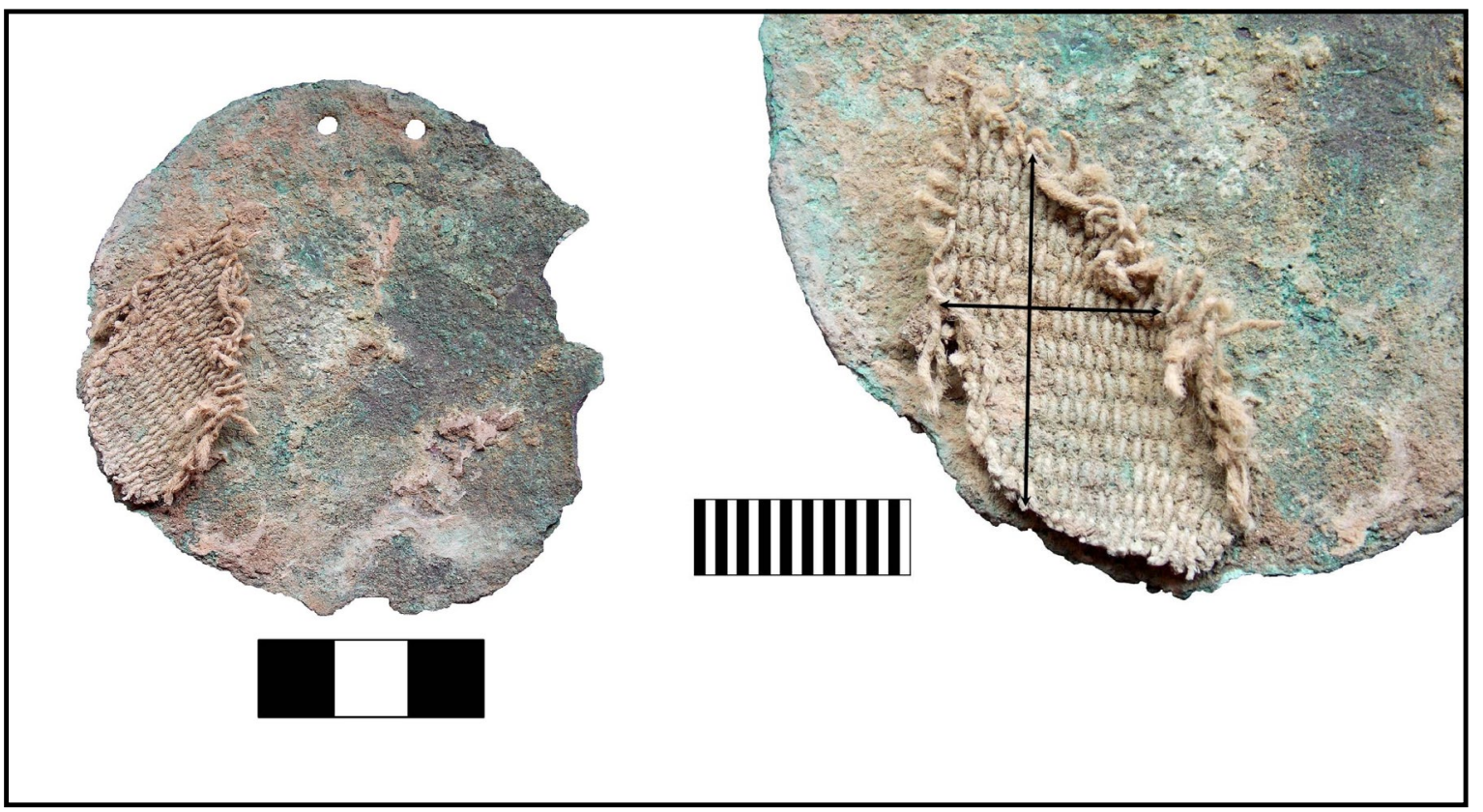

Figura 4. Vista general y detalle de la placa de metal y el fragmento de textil asociado.

Dimensiones máximas del textil: sentido urdimbres (vertical): 29,4 mm y sentido tramas (horizontal): $23,5 \mathrm{~mm}$.

Tabla 1. Síntesis de atributos tecnomorfológicos y dimensiones del fragmento textil.

\begin{tabular}{|c|c|c|c|}
\hline & \multirow{2}{*}{ Atributo textil } & \multicolumn{2}{|c|}{ Elemento estructural } \\
\hline & & Urdimbre & Trama \\
\hline \multirow{3}{*}{$\frac{\pi}{0}$} & Dimensiones (largo y ancho) & $29,4 \mathrm{~mm}$ & $23,5 \mathrm{~mm}$ \\
\hline & Espesor & \multicolumn{2}{|c|}{$1,5 \mathrm{~mm}$} \\
\hline & Densidad (unidades $\mathrm{x} \mathrm{cm}^{2}$ ) & $24 \mathrm{ur} / \mathrm{cm}^{2}$ & $5 \mathrm{tr} / \mathrm{cm}^{2}$ \\
\hline \multirow{6}{*}{$\frac{\mathscr{0}}{\frac{\pi}{0}}$} & Diámetro (o título) & $0,6-0,8 \mathrm{~mm}$ & $0,9-1,1 \mathrm{~mm}$ \\
\hline & Dirección de torsión & $z-2 S$ & $z-2 S$ \\
\hline & Ángulo de torsión & $45^{\circ}$ & $\mathrm{n} / \mathrm{d}$ \\
\hline & Segmentos $/ \mathrm{cm}$ & 18 & $\mathrm{n} / \mathrm{d}$ \\
\hline & Tensión de torsión & Ajustado & $\mathrm{n} / \mathrm{d}$ \\
\hline & Color Munsell & \multicolumn{2}{|c|}{$2.5 \mathrm{Y} 8 / 2$} \\
\hline
\end{tabular}

un punto de vista técnico-productivo, es relevante señalar que la confección de una pieza con esta estructura textil implica el manejo de un telar, es decir, un dispositivo para el montaje de los hilados de urdimbre que cuente con la presencia de lizos que permitan separar las sucesivas caladas, para el paso alternado de los hilados de trama entre los de urdimbre, en cada pasada.
A pesar de sus reducidas dimensiones, un conjunto de atributos relevados en el fragmento textil nos permite inferir un manejo técnico logrado y una relativamente buena estabilidad estructural de la prenda original. Nos referimos, en primer lugar, a una densidad de urdimbres o grado de tupidez media/ alta, con notable regularidad en el espaciado de los elementos constituyentes. El grado de cobertura de 
una tela influye no solo en su estabilidad estructural, sino que también puede incidir en el confort que brinda (mayor resistencia al frío, impermeabilidad, etc.) y, asimismo, es un factor relevante en lo que respecta a la apariencia final del producto textil (Mańosa, 2008). Se suma el registro de hilados de título fino (menores a $1 \mathrm{~mm}$ ), de grosor regular o uniforme y que presentan tensiones elevadas, aunque no en exceso, atributos que se traducen en una mayor resistencia a la rotura por tensión y que, además, en conjunto, son testimonio de una cierta destreza o grado de pericia en la manipulación y torsión de las fibras durante su proceso de transformación en hilados.

En lo que respecta al atributo de dirección final de torsión, las dos direcciones posibles (derecha o izquierda) de giro de las fibras y cabos hilados no dependen de la destreza manual de los artesanos (que pueden y de hecho giran los husos en ambos sentidos) y tampoco estarían determinadas por la materia prima. Se asume que "el hilar y el torcer hacia un lado $\mathrm{u}$ otro constituye una elección cultural, y que en los Andes representa un indicador del lugar geográfico de su manufactura [117]" (Agüero, 1994). Es decir, es el resultado de elecciones culturales que se sustentan en tradiciones textiles enseñadas y aprendidas a lo largo de las generaciones. En el caso del área andina meridional, se ha determinado que la dirección de torsión final "normal", o al menos mayoritaria, de los hilados de dos cabos es la derecha (S), empleándose la torsión zurda o izquierda final (Z) para la confección de hilados de dos cabos que serán usados en contextos de carácter ritual, o en otros en los cuales se precisa que esta torsión $\mathrm{Z}$ con "agencia mágica" despliegue su poder protector (p.e. día de la Pachamama, rituales funerarios, diversas enfermedades, parto, viajes, rituales de fertilidad, etcétera.; cfr. datos compilados y ejemplos arqueológicos en López Campeny, 2006-2007, 2014). Al respecto, la torsión final derecha $(\mathrm{z}-2 \mathrm{~S})$ de los hilados del textil aquí analizado se diferencia de la tradición de torsión final inversa $(Z)$, que caracteriza a la producción textil de la costa central y norte de Perú. ${ }^{15}$ En base entonces a este atributo de la direc-

15 Para un conjunto de prendas recuperadas en la región de Tarapacá, Agüero (2010) menciona que el tipo de hilados mayoritarios corresponden a los de torsión $2 Z-S$ ción final $\mathrm{S}$ de los hilados de dos cabos podemos, por lo pronto, descartar la posibilidad de que se trate de una pieza de tradición incaica.

La conservación excepcional del fragmento de tejido nos permitió abordar otro aspecto relacionado con su producción, como es la determinación taxonómica de la materia prima empleada para su confección. ${ }^{16}$ A partir de la observación, pudimos registrar la presencia de fibras de aspecto aplanado y con extremos redondeados, espiralados, con un lumen amplio en relación a paredes delgadas, una superficie lisa y la presencia de torsiones a intervalos regulares; que conformaban la materia prima de los hilados. La comparación de este conjunto de caracteres anatómicos observados en la muestra con material de referencia actual -capullos de algodón recolectados en las cercanías de Beltrán, en el departamento Robles, Santiago del Estero, próximo a Ruta Nacional 34- nos permitió concluir acerca de la presencia de fibras vegetales correspondientes a algodón (Gossypium sp.) (Figura 5).

La determinación taxonómica de las fibras del textil trae a la discusión la problemática ya señalada sobre el posible cultivo y/o empleo del algodón (Gossypium sp.) como materia prima en la región en tiempos prehispánicos, y las diversas implicancias que se desprenden a partir de este planteo, según veremos luego.

Entre los análisis efectuados se incluyó la toma de muestras del sedimento adherido a la superficie de la placa en el área de contacto entre ambos objetos. El objetivo fue efectuar una determinación polínica, en busca de indicadores que permitieran discutir la

(final derecha), pero destaca que "también hay prendas tejidas con hilados poco comunes, tales como monocromo regular $2 \mathrm{~S}-\mathrm{Z}$ " (final izquierda), e interpreta que esto último "puede deberse más que a la utilización de hilados con connotaciones mágicas (en el primer caso), a la introducción de prendas de otras tradiciones tecnológicas, ya sean incaicas o traídas por el inca (de la costa norte o centro-norte del Perú) [9]".

16 Se tomaron muestras tanto de los elementos de urdimbre como de trama, a pesar de su alta similitud macroscópica. Para la observación y el análisis microscópico de fibras del textil, previamente montada en un portaobjetos, se utilizó un microscopio óptico y el material fue observado a distintos aumentos (100x; 200x y 400x). 


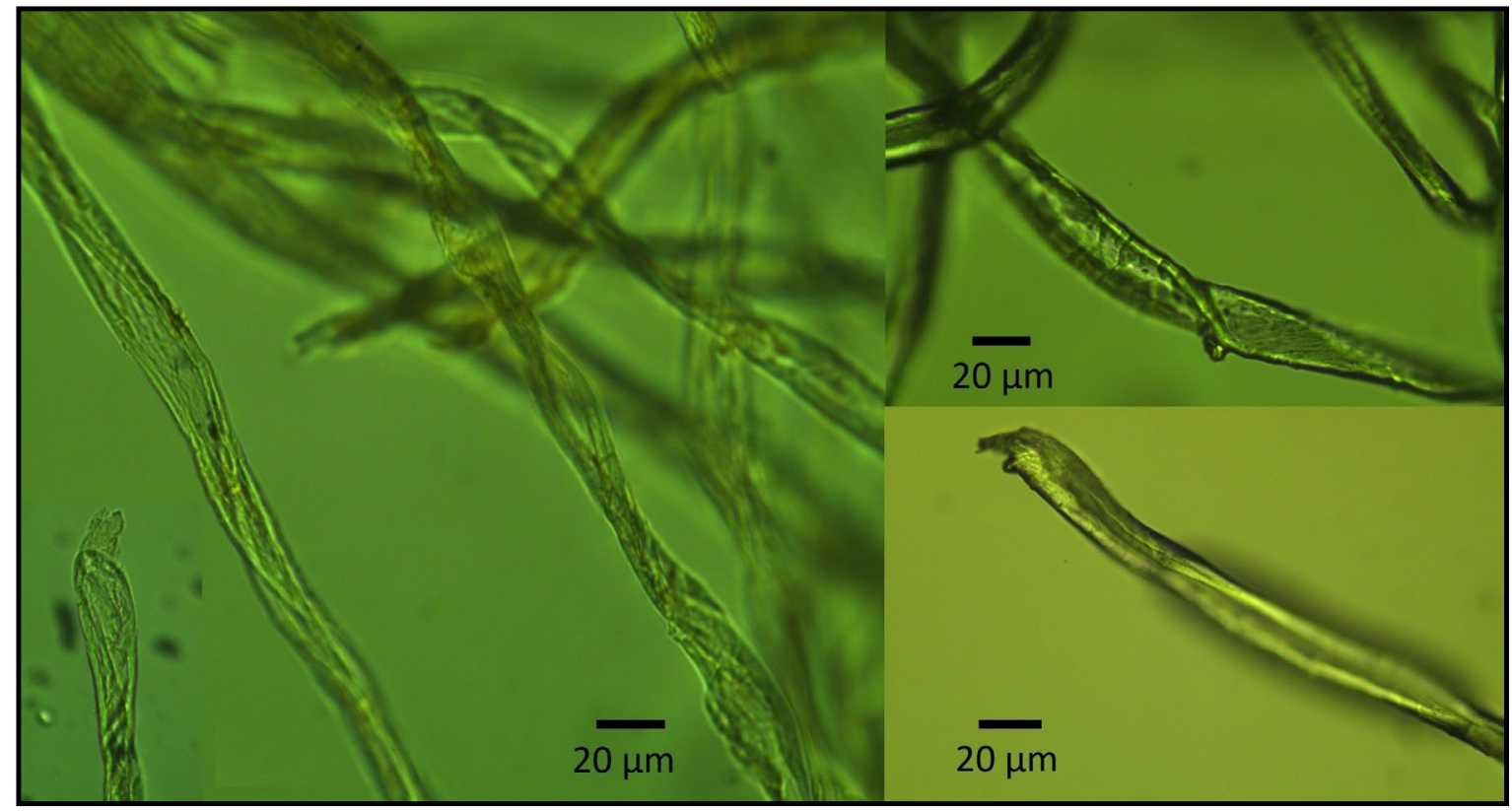

Figura 5. Izquierda: se observan rasgos diagnósticos en superficies, paredes y extremo de las fibras extraídas del fragmento textil asociado a la placa. Derecha (superior e inferior): material correspondiente a capullos de algodón actuales (Gossypium sp.), recolectados en la localidad de Beltrán, Santiago del Estero, año 2013.

posible circulación del objeto; pero la abundancia relativa de palinomorfos en la muestra no resultó estadísticamente significativa. ${ }^{17}$

Por otra parte, se procedió a realizar un fechado por AMS de una pequeña muestra de fibras vegetales extraída de la pieza (Tabla 2). El área relativa incluida bajo la curva de calibración de la fecha, a partir de la edad ${ }^{14} \mathrm{C}$ de la muestra, indica que existe una probabilidad de 0,85 de que la datación corresponda al lapso comprendido entre 1508 y 1582 DC. Es decir, la edad de la muestra queda comprendida en un rango temporal que no nos permite tener certeza de si la obtención de la fibra ocurrió al final del período prehispánico o en momentos coloniales tempranos. De todas maneras, ni la placa metálica ni el fragmento de textil presentan indicios estilísticos, tecnomorfológicos y/o composicionales que remitan a una elaboración hispana. Por el contrario, sus características nos permiten proponer para ambos objetos una manufactura, si no de época prehispánica, al menos de tradición indígena.

17 Los análisis fueron realizados por Andrés S. Romano (ISES, CONICET - IAM, UNT).
Tabla 2. Fechado ${ }^{14} \mathrm{C}$ del fragmento de textil asociado a la placa.

\begin{tabular}{|c|c|c|c|}
\hline Código & Edad ${ }^{14} \mathbf{C}$ & $\begin{array}{c}\text { Cal. } \\
\text { AD 1 sigma }\end{array}$ & $\begin{array}{c}\text { Área relativa } \\
\text { bajo curva }\end{array}$ \\
\hline AA101192 & $347 \pm 29$ AP & $1508-1582$ & 0,85 \\
& & $1620-1632$ & 0,15 \\
\hline
\end{tabular}

Calibration data set: shcal113.14c (Hogg et al., 2013).

En este contexto, es importante tener los recaudos que implica reconocer la diferencia existente entre el evento datado (que es el que efectivamente mide la técnica radiométrica, o sea, la extracción de la fibra de la planta en este caso) y los eventos de interés para nuestro estudio, es decir, la confección, el uso de la prenda y la asociación de la misma con la placa de metal. Este conjunto de eventos pueden haber sido relativamente sincrónicos entre sí, o más o menos inmediatos en el tiempo, o bien sucederse con distintos intervalos de temporalidad. Así, con el fechado de la fibra, tenemos la certeza de que la elaboración del textil no pudo ocurrir en momentos previos a la cronología obtenida (ante rem), pero luego entran en juego una serie de variables culturales, ya que las fibras pueden ser almacenadas previamente 
a su uso en la elaboración de los textiles y éstos, a su vez, luego de confeccionados pueden conservarse (reutilizarse, reclamarse, legarse) a lo largo de varias generaciones, pudiendo tener una vida útil extensa y cambiante. Entonces, en términos de los diferentes grados de certeza posibles de discriminar en la asociación muestra-evento (Carbonari, 1994; Waterbolk, 1983 en Greco, 2012), interpretamos que la relación de proximidad temporal entre la edad obtenida y la confección del textil es más probable que su relación con la fecha de uso o vida útil de la prenda, o con la fecha de asociación del textil con la placa. Estos últimos eventos pudieron extenderse mucho más adelante en el tiempo, a partir de la fecha obtenida con la datación. Similares consideraciones se aplican a la placa, para la cual no puede asumirse el rango del fechado como época de confección ni llegada de la misma a la región. La datación es indicativa, sí, de que la asociación placa-textil debe ser similar o posterior al resultado del fechado obtenido.

\section{(Rastreando) la procedencia de los materiales de estudio}

Los datos contextuales de los objetos en cuestión son casi nulos. La placa cuenta con un siglado (1888) que remite a una ficha en papel del MCAEDW y que parece haber sido confeccionada en la década de 1980. La misma se limita a una descripción de la pieza, aparentemente a partir de la observación de la misma y no a la reproducción de información original provista por su colector. No se consigna la procedencia ni hemos hallado información previa que incluyera datos de hallazgo. Sin embargo, como veremos, se presume que procede al menos de la provincia de Santiago del Estero.

La placa y el textil asociado fueron hallados al momento de hacer un relevamiento de los objetos de metal que integran las colecciones del MCAEDW, institución que alberga casi con exclusividad material procedente de Santiago del Estero. Se encontraba en una caja junto a otros objetos de metal de la provincia. Este contenedor, de factura moderna, indica que los objetos fueron acondicionados allí en tiempos más o menos recientes. Es decir, la caja no albergaba originalmente las piezas estudiadas, por lo que no se puede descartar que la asociación de los artefactos allí reunidos haya sido conformada en tiempos recientes. Dicha caja contenía el rótulo "Sequía Vieja", uno de los sitios más importantes del área de los Bañados de Añatuya y que habría tenido una gran significación regional en momentos preincaicos, incaicos y coloniales (Taboada, 2014; Taboada y Farberman, 2014, 2018). De él proceden la mayor parte de los objetos de metal incaicos hallados en Santiago y poco más de 6 mil torteros de los cerca de 12 mil hallados en el área. Sin embargo, la placa con el textil no puede ser asignada directamente a este sitio ya que no cuenta con el siglado característico que los Wagner - pioneros que excavaron profusamente en la zona y el sitio- le adjudicaban al material de Sequía Vieja (las iniciales SV o su nombre completo), ni con ninguna otra identificación. Aun así, cabe señalar que los hermanos Wagner no siempre siglaban las piezas, y que el sitio Sequía Vieja fue excavado también por Pedersen en 1941, quien aparentemente entregó al menos parte del material recolectado al MCAEDW. ${ }^{18}$ Aunque esta pieza no figura entre las que Pedersen (1952) ilustra en su trabajo, analiza la composición de una pieza procedente del sitio Averías cuya descripción podría corresponderse con la estudiada por nosotros: "pectoral circular plano sin pedúnculo [Cuadro II, p. 95]" (Pedersen, 1952). ${ }^{19}$ Lamentablemente la placa hallada por Pedersen en Averías no ha podido ser identificada en la colección del MCANEDW y no hay otras referencias que nos permitan evaluar si se trata de la misma pieza o no (ver González, 1992). En cualquier caso, la procedencia tendría similar significación, por cuanto Averías es otro de los grandes sitios de los Bañados de Ańatuya con evidencias incaicas y sobre ocupación hispana.

Pero hay también otro lugar de procedencia factible. La caja en cuestión incluía algunos objetos sin siglar y unos pocos con los nombres de otros tres sitios

18 Parte de la colección particular de Pedersen fue rematada en subasta pública en el año 1984 en Buenos Aires, y entre el material figuraban varias piezas de metal (González, 1992) y otros materiales (Vitry, s.f).

19 Los resultados de los análisis de composición realizados por Pedersen para esa pieza, y aquellos efectuados por nosotros para la pieza estudiada aquí, no son exactamente iguales, pero consideramos que en este caso no pueden compararse debido a que desconocemos las técnicas utilizadas por el mencionado autor. 
arqueológicos de Santiago del Estero: Chilca, Pozo Verde y Manogasta. Para el último caso se indica, además, que la pieza pertenece a la Colección Argañaraz. Estos tres parajes, ubicados en el área de influencia del río Dulce, fueron excavados por Jorge Argańaraz en la primera mitad del siglo XX, y es probable que estas piezas pertenezcan a su colección. No es imposible que nuestro objeto de estudio proceda también de la misma colección, en vista a una referencia bibliográfica que especifica la conservación de prendas de vestir adheridas a objetos de metal, entre ellos "discos", en un contexto de inhumación múltiple, aparentemente colonial, excavado por Argañaraz. Este investigador relata, en una carta a Antonio Serrano que: "A una profundidad de un metro sesenta habían depositado sus muertos en una cantidad y hacinamiento muy grande. Es allí donde recogí las perlas, así como abundantes objetos en bronce y plata de confección típica calchaquí, tales como: campanillas, tazones de variadas formas, tumis, alfileres, pendientes, discos pectorales, brazaletes y hasta fragmentos de sus vestidos que estaban adheridos a los brazaletes y discos pectorales. ${ }^{20}$ Todo esto acompañado con objetos de hierro de origen europeo [112]" (Serrano, 1938, resaltado nuestro). No se aclara el nombre del sitio, pero luego Reichlen (1940 [155-156, 165-166]) hace referencia a una situación que parece ser la misma mencionada por Argañaraz para Savagasta, un sitio en el área de influencia del río Dulce que fue asiento de un Pueblo de Indios colonial (Gramajo, 1992), y del que no hay datos para evaluar su situación en momentos prehispánicos. Savagasta designa, entonces, o la ubicación del relato hecho por Argańaraz a Serrano, o una situación casi idéntica a esa que se repite, o un nombre erróneo, ya que a pesar de nuestras pesquisas no tenemos registro de ningún material arqueológico procedente de Savagasta que fuera publicado ni identificado en el MCAEDW, o en el Museo de Antropología de Córdoba, donde se conserva otra parte de la Colección Argañaraz (Andrés Izeta, com.

20 Hay que considerar que la alusión a "disco pectoral" puede ser inespecífica respecto del uso o función de la pieza, en tanto que es un término usualmente empleado para diversos tipos de objetos no necesariamente usados como pectorales. En este caso no sabemos si a los objetos metálicos mencionados se los halló cumpliendo tales usos sobre los restos humanos o si integraban ajuares dispuestos de otra forma. pers., 2015). ${ }^{21}$ Sí hay en dichos museos, en cambio, objetos procedentes de Manogasta, sitio excavado también por Argañaraz y que fue un importante y temprano Pueblo de Indios colonial del Dulce donde se hilaba algodón (Bonetti, 2013; Farberman, 2008; Gramajo, 1992; Levillier, 1918; Lorandi, 2015; Serrano, 1938), emplazado posiblemente sobre un asiento prehispánico. En las inmediaciones del pueblo actual de Manogasta se registran en superficie restos de factura indígena (como cerámica Averías y torteros) e hispana (Bonetti, 2013; Lorandi, 1978, 2015), pero el sitio no ha sido objeto de estudios arqueológicos modernos.

Ahora bien, lo significativo es que en el relevamiento de objetos de metal que realizamos en el MCAEDW se registraron dos tipos de piezas que coinciden con algunas de las señaladas en la carta de Argañaraz (cascabeles y brazaletes) que poseen la particularidad de presentar pseudomorfos textiles en la pátina (Angiorama et al. 2018). Su procedencia en algunos casos no consta y en otros remite a Manogasta. Esta característica de conservar evidencias indirectas de asociación con textiles no es común entre las piezas de metal recuperadas en la provincia de Santiago del Estero, ya que del total relevado por nosotros hasta ahora solo lo presentan las mencionadas, aportando a la idea de que el relato del hallazgo pueda referirse a Manogasta, o de que allí se realizó un hallazgo similar al descripto en la carta. Una duda la introduce la significativa diferencia de conservación entre nuestro objeto de estudio y las piezas de Manogasta relevadas (en su mayoría fragmentos muy corroídos) y que hacen presumir diferentes contextos de depositación o ambiente de preservación, e incluso modo de recuperación. En cambio, gran parte de los objetos de metal hallados en los Bañados de Añatuya muestran características de conservación similares a nuestra pieza de estudio: muchos se encuentran completos, en bastante buen estado de conservación y con una pátina superficial, lo que se suma a la posibilidad de que la pieza fuera hallada en esa región. También hay referencias de que se hallaron fragmentos textiles en esta zona.

21 Sin embargo, hay que tener en cuenta que en los museos mencionados existe material originalmente no siglado $\mathrm{y}$ en proceso de fichaje moderno, lo que no permite ser absolutos en esta consideración. 
En síntesis, las posibilidades más factibles son: que la placa y el textil adherido hayan sido hallados en Sequía Vieja (o Averías) por los hermanos Wagner o por Pedersen, en un contexto desconocido dentro de sitios con ocupacion prehispánica tardía y colonial, o bien en Manogasta por Argañaraz, en un contexto de inhumación colonial.

\section{Discusión}

\section{Sobre el posible uso del algodón y otras fibras en tiempos prehispánicos}

Para abordar este tema, lo primero que debemos hacer es diferenciar espacial, temporal y culturalmente los datos disponibles, ya que Santiago del Estero es una amplia región que presenta variantes ambientales y un proceso histórico extenso y diverso. Esta diversidad ha tendido a quedar oculta en una generalización referida a la región Chaco-Santiagueña como un todo homogéneo (Taboada, 2011).

Empezando por las fibras animales, debemos decir que aún no se cuenta con suficientes estudios específicos ni determinaciones afinadas para conocer las especies y el manejo que las distintas poblaciones locales hicieron de los camélidos que se identifican a partir de las evidencias óseas halladas en la provincia. Las dudas más significativas para el tema se refieren a si hubo (y desde cuándo y en qué zonas) camélidos domesticados, y al impacto del clima y vegetación en la potencial producción de fibra de este origen -en cuanto a su cantidad y calidadcomo para considerar la posibilidad para Santiago del Estero. Estudios zootécnicos realizados en Perú muestran que ciertas condiciones ambientales no favorecen la cría de animales domésticos con fibra de calidad adecuada para un uso textil (longitud, grosor, densidad, etc.), aunque los animales puedan efectivamente criarse y vivir en el área (Quispe, Rodríguez, Ińíguez y Mueller, 2009). Estas condiciones ecológicamente adversas incluyen varias de las presentes en la llanura santiagueña, tales como: un ambiente muy cálido y estacionalmente húmedo, una vegetación predominantemente arbustiva y la proliferación de parásitos y hongos.
En función de las variables climáticas imperantes es que Lorandi discutió la posibilidad de contar en la llanura santiagueña con llamas que proveyeran materia prima de calidad y en cantidad para tejido. Sostuvo, en base a ello, la probable existencia de rebaños en los sectores serranos de la provincia, donde pudo haber colonias de pobladores de la llanura (Lorandi, 1978, 2015). Los resultados de análisis realizados por su equipo sobre materiales arqueofaunísticos de la zona del río Salado y la mesopotamia santiagueńa, fechados $c a$. entre los ańos 1000 y el 1400 DC, no permitieron identificar si había llamas. Sobre la base de los criterios del momento, algunos fueron definidos como guanacos (contextos de la fase Las Lomas), mientras que otros como camélidos no identificados (contextos de la posterior fase Quimili Paso) (Cione, Lorandi y Tonni, 1979; Lorandi, 1978, 2015). Esta situación es congruente con otras apreciaciones que llevaron a caracterizar a la economía de esas zonas y épocas como mixta, con un fuerte componente de caza, pesca y recolección, con horticultura o agricultura de bajo rendimiento (Lorandi, 1978; Lorandi y Lovera, 1972). Por su parte, para momentos de contacto, al menos algunas poblaciones habrían desarrollado una agricultura con posible manejo hidráulico que las propias fuentes refieren y los datos arqueológicos parecen acordar (Lorandi, 1978, 2015; Ortiz, Collantes, Zapatiel y Burgos, 2016; Wagner y Wagner, 1934). Lamentablemente, no se cuenta con determinaciones arqueofaunísticas para dichos contextos prehispánicos finales de la mesopotamia santiagueña y el Salado (fase Oloma Bajada Icaño).

Por su parte, y de acuerdo con la hipótesis de Lorandi, nuevos estudios han señalado la identificación de restos de llama en el sitio Maquijata, ${ }^{22}$ ubicado en

22 Cabe aclarar que en el paraje de este nombre se han hallado varios sitios arqueológicos de distinta temporalidad y asociación cultural (Gramajo y Martínez Moreno, 1992; Ledesma, 1961; Togo, 2004) y el referido no parece corresponder, según los datos aportados por Togo y Del Papa, al asiento o Pueblo de Indios de la Encomienda de Maquijata (Gramajo, 1992). Según un expediente analizado por Ferreiro (1997), los indios de esta encomienda se movían entre dos instalaciones: una localizada en la zona en cuestión, en algún sitio posiblemente cercano al actual pueblo de Maquijata -pero por el momento no identificado como tal por ningún autor- y otra en la sierra de El Alto-Ancasti en Cata- 
las Sierras del oeste provincial, y en otros sitios de esa zona y de la cuenca del Dulce (Del Papa, 2012a, 2012b). Están asociados a contextos con fechados que abarcan desde los primeros siglos de nuestra era hasta época prehispánica tardía (Del Papa, 2012a; Togo, 2004); pero no hay datos seguros asignables a contextos prehispánicos finales. Una cita que refiere la existencia de "corrales de ovejas como las del Perú [52]” (Diego Fernández, 1571/1987), parece ser definitiva en relación a pensar la cría de camélidos domésticos en la llanura al momento de contacto. La cita se ha interpretado como referida a la zona de las Sierras de Guasayán o el Dulce (Lorandi, 2015; Raffino, 1975), pero una mayor especificidad espacial en torno a un ámbito de llanura podría derivarse de una observación de Lorandi (2015). La autora señala que el patrón de asentamiento poblacional descripto por Fernández al continuar el relato mencionado es el que se registra tanto en la zona de llanura del Dulce como del Salado, y nosotros podemos agregar que, por otros datos arqueológicos (Gramajo y Martínez Moreno, 1992; Togo, 2004), no parece ser el patrón de la sierra.

En definitiva, el conjunto de datos parece mostrar, por ahora, diferencias espaciales, temporales y culturales en cuanto al manejo de los camélidos y la fibra animal. Mientras que para la zona del Salado y para la mesopotamia se cuenta con registros interpretados en la década del setenta como guanacos y camélidos no identificados a nivel de especie entre $c a$. el 1000 y 1400 DC, y no hay datos certeros acerca de la existencia de llamas (pero no puede negarse esta posibilidad), para el oeste provincial se ha propuesto actualmente la presencia de guanacos y de llamas, asociados tanto a contextos Formativos como Tardíos. Sin embargo, para ninguna de las dos áreas tenemos aún datos arqueofaunísticos asignables a momentos prehispánicos finales y de contacto (siglo XV y XVI), aunque las fuentes referidas podrían indicar la existencia de corrales y el uso de atuendos confeccionados en fibra animal (¡camélido?), al me-

marca. Ver más adelante comentarios al respecto. Para momentos más tempranos también es posible señalar interacción o integración con comunidades formativas aldeanas del piedemonte (Gramajo, 1992; Lorandi, 1967, 1978; Taboada, 2011; Togo 2004), que pudieran dar cuenta del conocimiento y/o práctica del pastoralismo en la zona. nos en algún lugar del espacio regional. De todos modos, es importante dejar en claro que ni aun la identificación de restos óseos asignables a especies domésticas de camélidos, ni el registro de otros indicadores que dieran cuenta de un manejo o control de los rebaños, constituirían prueba suficiente para aseverar un aprovechamiento con fines textiles de sus fibras; máxime si consideramos la situación ecológica y ambiental local antes referida como posible limitante para este uso.

Por su parte, algunas referencias como la señalada por Sotelo de Narváez (1582/1885) que dice que "bestíanse los varones de plumas de avestruces con que tapaban sus vergüenzas y unas mantas muy pequeñas que se hacían de cierta paja y lana de algun ganado que tenían de la tierra [144]"; o bien aquella que afirma que en las riberas de El Salado hay "mucha abundancia de pez y cabuya que sirve de cáńamo [145]"; permiten plantear también el uso de fibras vegetales silvestres. En este sentido, es interesante la reflexión de Boman (1908/1991) respecto a que "Los españoles del tiempo de la conquista parecen haber aplicado, en cualquier región de la América española, el nombre caribe de cabuya a todas las plantas textiles de hojas espinosas bromeliáceas en general [...]. El nombre quichua que corresponde a cabuya es chahuar y el nombre guaraní, caraguata [101]". En acuerdo con su reflexión, consideramos que estas citas, así como otras similares, ${ }^{23}$ estarían aludiendo al empleo de ciertas bromeliáceas locales para la confección de elementos textiles, en el marco de prácticas que interpretamos serían de tradición prehispánica. Y a pesar de que no contamos hasta el presente con referentes arqueológicos directos, que para momentos prehispánicos testimonien tal procesamiento textil de fibras vegetales semi rígidas, consideramos que tampoco podemos descartar esta posibilidad

23 El procurador Alonso de Abad (1585) informa que entre los vecinos de Santiago "no se podia hallar otra cosa para vestimentos sino cueros de benados que los dichos conquistadores aderesauan y camisas de una cabuya sacadas de unas espinas [125]" (Levillier, 1918). Para la misma fecha, Arévalo y Briceño (1585) menciona que en los repartimientos de Soconcho y Manogasta la ropa se hace mayormente de algodón y "demás desto lo hazian de un hilado que llaman cabuya o chaguar [7]”. El destacado es nuestro. 


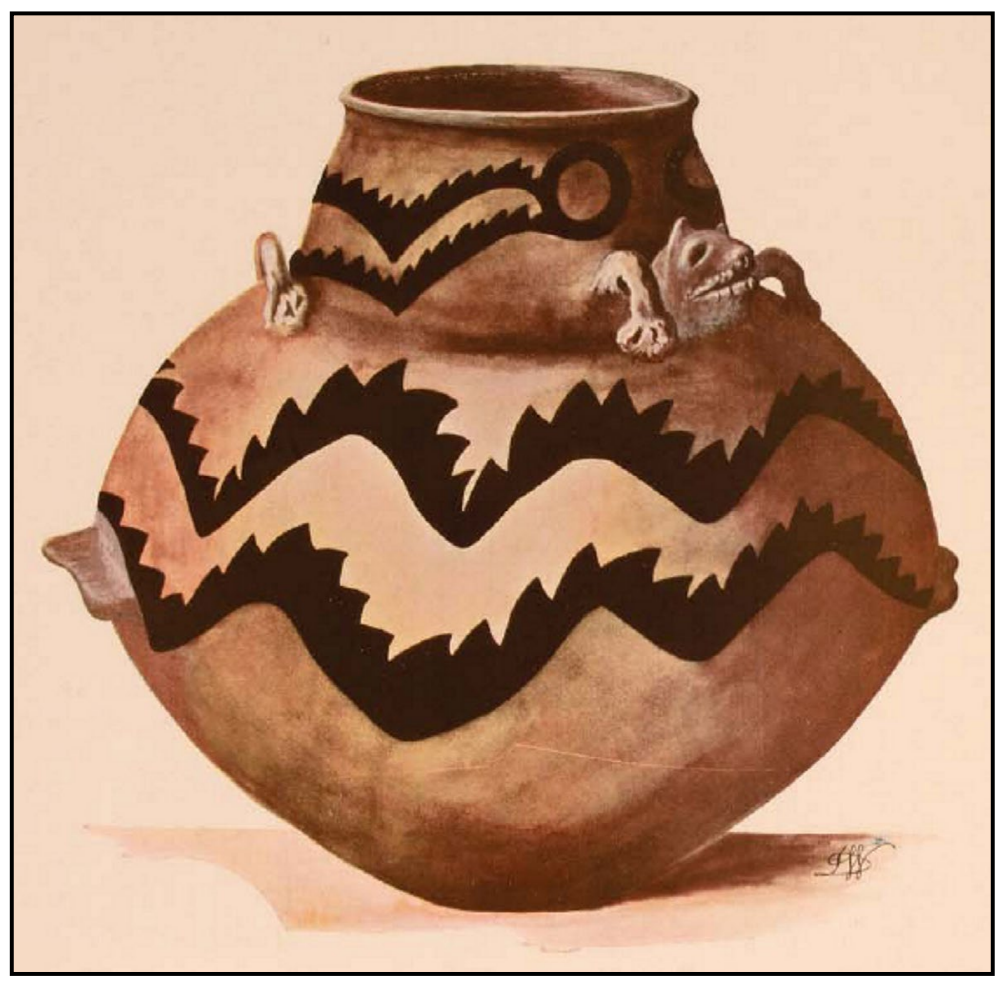

Figura 6. Urna arqueológica asociada al hallazgo textil estudiado por D’Harcourt (1932) ilustrada luego por Wagner \& Wagner (1934, fig.1, lám. I).

si nos apoyamos en la información desprendida de las crónicas tempranas.

Ahora, con respecto al algodón, es claro que las condiciones climáticas imperantes en la llanura santiagueña son las óptimas para su crecimiento. La distribución del género Gossypium se encuentra limitada a latitudes tropicales y subtropicales, ya que las distintas especies no son tolerantes a las heladas y sus ciclos de crecimiento anual están ligados a la alternancia de estaciones secas (invierno) y húmedas (verano) (Stephens, 1975, en Andreoni, Spano y Lema, 2012). En lo que respecta a la información arqueológica disponible, las evidencias más antiguas de uso de esta planta en el NOA corresponden en el presente a contextos con cronologías fechadas entre ca. 2000 a 1400 ańos AP. ${ }^{24}$ Se trata de fibras de Gossypium sp., identificadas entre los microrrestos conservados en el contenido carbonizado de un conjunto de hornillos de pipas. Las mismas proceden

24 Para un análisis sobre las evidencias y discusiones al respecto, consultar Lema y Capparelli (2007). de un grupo de sitios (Soria 2, Campo Colorado, Arroyo Colorado, Fraile Pintado y El Taco 19) emplazados en las actuales provincias de Salta, Jujuy y Catamarca (Lema et al., 2015). Los autores citados interpretan la presencia de las fibras de algodón en relación a actividades de limpieza o a la colocación de tapones a modo de filtros en las pipas.

En función de lo dicho, parece no haber habido restricciones para que, al menos las poblaciones prehispánicas tardías de la llanura santiagueña que habían desarrollado la capacidad de producción agrícola, cultivaran y usaran esta fibra en el hilado (y tejido), actividad que los torteros de la zona parecen indicar para esa época. Más aún, parecería ser la fibra más accesible en esa situación. Sin embargo, no hay datos concretos al respecto para nuestra área de interés. Solo contábamos hasta ahora con el estudio técnico efectuado por D'Harcourt (1932) que ya anticipamos (nota 7) sobre un fragmento textil recuperado en el interior de una urna arqueológica (Figura 6). Allí el especialista finaliza la descripción de la pieza mencionando que los hilados podrían corresponder 
a fibras "de origen vegetal (¿algodón?)" (sic. [190]) $)^{25}$ (D'Harcourt, 1932). Sin embargo, lo impreciso del comentario, además de la carencia de alguna referencia sobre la metodología usada para la identificación de las fibras, nos lleva a suponer que el autor solo realizó una apreciación general basada en una observación superficial de la pieza. A ello se suma la falta de datos contextuales sobre el hallazgo, que se recuperó en el interior de una vasija hallada por Helman Gauna, luego donada al MCAEDW (Righetti, 1942; Wagner y Wagner, 1934). Además, tanto el análisis de las características de la urna, atípicas en relación a cerámicos locales más característicos, como su posible, como su posible procedencia de la zona de las sierras de Guasayán, llevan a pensar que se trata de una pieza que no ejemplifica una situación común en la llanura santiagueña. ${ }^{26}$

Como sea, es incuestionable el uso y cultivo local del algodón durante la Colonia (Assadourian, 1982; Castro Olañeta, 2013a, 2013b; Doucet, 1986; Farberman y Boixadós, 2006; Ferreiro, 1997; Garavaglia, 1986; Lorandi 1988), pero basado en algunas fuentes que relatan su introducción por los españoles desde Chile, se ha asumido que los pobladores prehispánicos de la llanura santiagueña no

25 La traducción es nuestra.

26 Existe un problema acerca de la procedencia de esta urna. Por una parte se indica que procede de la zona de Icaño (Bañados de Añatuya) (Righetti, 1942) y por otra, de "Guasayán (mesopotamia santiagueña) [85]" (sic) (Wagner y Wagner, 1934) (cuando en realidad Guasayán se localiza en el sector serrano del oeste santiagueńo). Por la zona en la que trabajó Gauna, es más probable que proceda de las sierras de Guasayán o del Dulce. Los Wagner (Wagner y Wagner, 1934) la asignan a la Rama B de la Civilización Chaco-Santiagueña, pero la vasija posee un tipo de decoración que difiere de los estilos clásicos registrados en Santiago del Estero, aunque hay algunas piezas con representaciones y formas parecidas a ella ilustradas por los Wagner (Wagner y Wagner, 1934: figuras 304 [111] y 317 [116] y lám. XLVII). Piezas similares fueron recuperadas por Von Hauenschild, Delgado y Argañaraz en Beltrán (área del río Dulce) y San Juan (también sobre el Dulce). El felino emergiendo de la vasija, en cambio, no está presente en ninguna otra pieza que conozcamos de la región, y difiere de las representaciones felínicas modeladas registradas en la alfarería de Santiago. Podemos concluir que no se trata de un ejemplar típico ni generalizado en Santiago del Estero para tomar como referente. lo cultivaban. El relato en cuestión se debe al Alcalde Ordinario de $1^{\circ}$ Voto de Santiago del Estero, Juan Cano de la Banda (1583), quien describe las penurias y carencias de los vecinos españoles en la época de la fundación de esta ciudad, y menciona que, ante los reiterados reclamos, son asistidos por un sacerdote que llega desde Chile: "que venido el sacerdote e traydose las plantas e semillas de algodón que tiene dicho, los españoles se quietaron mucho más en la tierra e se dieron a sembrar el dicho algodón"(Levillier,1920, en Corcuera, 2006 [2324]). Hay también otras menciones tempranas, para fines del siglo XVI (1586), acerca de la siembra de algodonales, como el caso de Simón de Villadiego, vecino de la ciudad de Santiago del Estero (Lizondo Borda, 1936 [71-73]). La primera cita ha sido normalmente interpretada como una introducción del cultivo a la región, pero Lorandi (2015) ha planteado que quizás pudiera tratarse de una reintroducción de un cultivo prehispánico perdido, tal vez por la quema de sementeras por parte de los propios indígenas. Si bien las evidencias arqueológicas no son determinantes, no inhabilitan tal idea, y algunos datos y citas podrían apoyarlo. En este sentido, Inca Garcilaso de la Vega (1609/1960) da cuenta de que en las tierras del Tucumán -aunque sea una referencia general cobra más sentido con la cita siguiente-, entre los bienes entregados al Inca Yupanqui en prueba de amistad y vasallaje se cuenta "mucha ropa de algodón [262]", y también comenta que "En los llanos donde por ser tierra caliente no visten lana, hacían ropa de algodón de la cosecha de las tierras del sol y del Inca” (ibíd., resaltado nuestro), en concordancia con nuestra hipótesis de que entre los posibles intereses del Inca en las tierras bajas pudieron estar efectivamente las materias primas y las habilidades de los pobladores locales. Recordemos, además, los torteros hallados en sitios incaicos de los valles del NOA que son casi idénticos a los registrados en grandes magnitudes en la llanura santiagueña (Taboada et al., 2013), aptos para el hilado del algodón según los trabajos de López Campeny (2011-2012).

Otras fuentes, en cambio, parecen indicar que el uso de la ropa de algodón se da recién después de arribados los españoles, siendo antes de algún otro vegetal y/o de fibra animal. Dice Castro Olañeta (2013b): "Lo interesante de esta fuente es que Sotelo... va 
marcando diferencias entre la situación inicial del contacto y la del momento en el que escribe, casi 30 años después: 'criaban abestruces mansos en sus casas y gallinas, patos y asi lo hacen ahora, aunque despues que los cristianos entraron en aquella tierra se visten todos en general al fuer de los del peru de lana y de algodón [7]'”. Hay que aclarar, sin embargo, que no contamos con precisiones para evaluar a qué espacios concretos y grupos poblacionales se refiere el cronista (Castro Olañeta, com. pers. 2016). Esto es relevante ya que el vestido era un factor fundamental de distinción de grupos y naciones por parte de los españoles (Farberman y Taboada, 2012). Dichas clasificaciones bien pudieron estar reflejando diferencias culturales al interior del territorio, entre ellas, diferente acceso y manejo del hilado, tejido y fibras usados en la vestimenta. Una referencia espacialmente bien situada, en cambio, es la que refiere que en Soconcho y Manogasta, sobre el río Dulce, el algodón "es vestido de los naturales de esta tierra [10]" (Arévalo y Briceño, 1585), ${ }^{27}$ aunque ya en el marco de encomiendas especializadas en dicha producción.

De hecho, para momentos coloniales, varias fuentes dan cuenta de que "el beneficio del algodón" era una actividad relevante en el marco de los tributos entregados y las actividades del servicio personal desarrolladas en los pueblos de indios y las encomiendas tempranas de Santiago del Estero integradas a la Gobernación del Tucumán (Arévalo y Briceño, 1585; Ferreiro, 1997; Freyre, 1915; Garavaglia, 1986; Lorandi, 1988). Entre éstos, Soconcho y Manogasta tenían una larga tradición textil y eran conocidos en el siglo XVI como "repartimientos ricos en ropas [52]" (Garavaglia, 1986). Más aún, de esos pueblos gozaban los gobernadores del Tucumán (Farberman, com. pers. 2016). Es significativo, sin embargo, que un documento del ańo 1585 que refiere a Sonconcho y Manogasta menciona que el administrador debe comprar el algodón porque "estos dos repartimientos no tienen algodonales o mui poco [11]" (Arévalo y Briceño, 1585), y que deberá "buscar tierras y plantar algodon para que no sea necesario comprarlo si no fuere los dos años prime-

27 Agradecemos a Judith Farberman por facilitarnos el acceso a este documento inédito, relevado por ella, y por señalarnos que contenía información relevante para nuestra investigación. ros [11]" (Arévalo y Briceño, 1585). Algo similar sucedía con la encomienda de Maquijata, donde el hilado y tejido del algodón eran las principales actividades de sus integrantes (Ferreiro, 1997). Debemos notar aquí también que el algodón debía ser llevado desde otro lugar al pueblo donde se asentaba la encomienda de Maquijata, en las Sierras de Guasayán, ${ }^{28}$ en este caso desde áreas como la sierra de El Alto-Ancasti, Sumamao y Tuama (en el Dulce), y Esteco (Salta), porque allí no se producía. Para el Salado tampoco parecen conocerse referencias específicas de cultivo (Castro Olañeta, com. pers. 2016) y se ha hipotetizado que, al menos en algunos casos, el que allí se tejía también pudo haber sido llevado desde otro lugar como parte de una estrategia colonial de complementariedad (ver hipótesis al respecto en Castro Olañeta y Carmignani, 2017).

En el caso de Soconcho y Manogasta se dice que el problema es que hay poco algodón y que los indios no cultivan sus sementeras (no dicen específicamente si las de algodón), ni hacen sus ropas si no les dan el algodón y si no los apremian para ello [12] (Arévalo y Briceño, 1585), pero se entiende que podría cultivarse en la zona. Como sea, lo dicho reafirma su cultivo al menos en algunos sectores de la llanura santiagueña, en la sierra catamarqueña vecina, y en Esteco, al norte del Salado en pleno ambiente chaqueño. A la vez muestra cierta necesidad o práctica de aprovisionarse de otras zonas (como pudo ser el caso de la importación desde Chile discutido por Lorandi, que comentamos antes), por razones que no pueden ser asignadas a un desconocimiento del cultivo del mismo en nuestra región. En otro orden de cosas, es significativo notar que la encomienda de Maquijata compra algodón a Esteco, una población ubicada a mayor distancia que aquellas ubicadas en la sierra y valle de Catamarca.

28 Esta encomienda se caracterizó por el hilado de algodón (Ferreiro, 1997). Es interesante al respecto que entre algunos de los sitios de la zona se ha reportado la presencia de torteros pequeños e incisos (Ledesma, 1961), del tipo de los hallados en la zona de los Bańados de Añatuya que López Campeny (2011-2012) considera aptos para el hilado de algodón. Podrían interpretarse en relación, si no a la encomienda, al menos al desarrollo de esa práctica en la zona. 
A las evidencias históricas en torno al cultivo, hilado y tejido del algodón enumeradas hasta aquí se suman las arqueológicas recientemente generadas por nuestro proyecto: el fragmento textil adherido a la placa metálica que presentamos en este trabajo y la comprobación de la práctica de hilado local, en momentos pericoloniales, en Sequía Vieja -donde en tiempos coloniales se habría asentado el Pueblo de Indios de Lasco (Taboada y Farberman, 2018)-. En este último caso, los restos de hilado fueron recuperados a través de la toma de muestras de sedimento adherido a las superficies de torteros recuperados en nuestras excavaciones. ${ }^{29}$ Esto ha permitido la identificación de hilados confeccionados en fibras de algodón (Gossypium sp.), uno de ellos con evidencias de teñido (rojo) (López Campeny y Taboada, 2016), asociados al sedimento adherido a la hendidura lateral y orificio central de un tortero con motivos incisos procedente del piso interior de una vivienda de Sequía Vieja (SV150) (Taboada, 2016). En el piso habitacional no se hallaron hasta el momento indicadores de época colonial, sin embargo, los depósitos de relleno sí los muestran en escasa proporción. De hecho, sabemos que el sitio tuvo ocupación prehispánica y poscontacto (Taboada, 2014; Taboada et al., 2015). El fechado radiocarbónico sobre espículas de carbón recuperadas del piso del recinto tampoco es determinante, ya que abarca un rango temporal prehispánico-colonial (con el potencial problema de envejecimiento de maderas reutilizadas). La fecha obtenida es similar a la de la tela analizada en este trabajo, situando los hilados en momentos pericoloniales, pero con una mayor probabilidad de que daten de tiempos prehispánicos (Tabla 3) (Taboada, 2016).

Tabla 3. Fechado ${ }^{14} \mathrm{C}$ asociado al tortero con hilados de algodón de SV150 (Taboada, 2016).

\begin{tabular}{|c|c|c|c|}
\hline Código & Edad ${ }^{14} \mathbf{C}$ & $\begin{array}{c}\text { Cal. } \\
\text { DC } 1 \text { sigma }\end{array}$ & $\begin{array}{c}\text { Área relativa } \\
\text { bajo la curva }\end{array}$ \\
\hline LP-2993 & $460 \pm 50$ AP & $1432-1500$ & 0,88 \\
& & $1597-1611$ & 0,12 \\
\hline
\end{tabular}

Calibration data set: shcal113.14c (Hogg et al., 2013).

29 Estos procedimientos de extracción del sedimento adherido para recuperación y posterior identificación de microrrestos, se efectuaron bajo observación controlada con lupa binocular estereoscópica (40X).
Aunque dicha situación no defina el problema del origen del usufructo del algodón, duplica los casos de uso de esa materia prima potencialmente asignables a momentos prehispánicos tardíos, con un caso que puede ser ubicado con precisión en uno de los sitios de mayor importancia prehispánica del área de los Bañados de Añatuya. Por otra parte, confirma el hilado local del algodón en el Salado y el uso, para ello, de torteros tardíos, pequeños y livianos (diámetro: $3,4 \mathrm{~cm}$ y peso: $12,4 \mathrm{~g}$.); como se propuso para este tipo de pesos de hilar en base a la información actual compilada y analizada (López Campeny, 2011-12), y a los análisis experimentales de resistencia mecánica efectuados sobre fibras de distinta naturaleza (López Campeny et al., 2017; Romano y López Campeny, 2015).

Por su parte, cabe señalar que la mayor proporción de los torteros recuperados en los sitios de los Bañados de Ańatuya, donde aparecen en las grandes cantidades mencionadas, están intactos. Esto implica que tal magnitud no responde a una renovación de implementos descartados por rotura, sino a objetos extraviados o desechados por algún motivo, o a una situación en la que muchos de ellos pudieron ser utilizados simultáneamente o a una producción con fines de "exportación" de los mismos y no necesariamente de uso in situ que podría pensarse en relación al proceso incaico. En este sentido, no se puede dejar de pensar en que los Pueblos de Indios coloniales a los que hacemos referencia, como específicamente Lasco, que parece se emplazó sobre el poblado prehispánico conformando el sitio multicomponente de Sequía Vieja (Taboada y Farberman, 2018), contaba por el año 1607-1608 con un total de solo 535 individuos, de los cuales 154 eran indias de hilado (Castro Olañeta, 2013b). Sin embargo, las encomiendas de la zona habrían sido antes las más numerosas del territorio (Castro Olańeta, 2013b), mostrándonos una población prehispánica local de gran envergadura -también estimada a partir de otros documentos tempranos (cfr. Palomeque 2005; Taboada y Farberman, 2014) - respecto de la gran reducción que sufre en pocos años. En función de este cambio drástico y relativamente rápido de la magnitud poblacional, y de las cifras mencionadas para Lasco (según nuestra hipótesis Sequía Vieja) para principios del siglo XVII, la enorme cantidad de torteros hallados en Sequía Vieja (se calculan no 
menos de 5 mil ejemplares procedentes de este sitio en la colección del MCAEDW y puede aún haber más en los contextos del asentamiento) parece demasiado alta para remitirlos exclusivamente a la población de hilanderas que pudo actuar en ese solo asentamiento en tiempos coloniales, aun en diferentes momentos. Aunque no hay datos concluyentes, la cifra parece estar más acorde con la demografía prehispánica del área, y con su continuidad de uso durante la Colonia. En concordancia, excavaciones recientes realizadas en el sitio de Sequía Vieja parecen indicar que al menos algunos de estos implementos se asocian a contextos prehispánicos finales coincidentes con época incaica (Taboada, 2014). Al respecto es sugerente, en el marco de la problemática que venimos planteando para la zona en épocas de la expansión incaica, que ciertos documentos coloniales referidos a litigios reúnen testimonios de indígenas que mencionan la práctica de los soberanos -en este caso puntual el Inca Huaina Capacde conformar establecimientos de mitimaes o "islas" de artesanos trasladados, luego reasentados en otras regiones. En dichos casos, las cifras que se refieren a los tejedores reimplantados alcanzan el orden de los mil artesanos textiles (Murra y Morris, 1976). Esta idea es parcialmente consecuente con las últimas hipótesis que planteáramos sobre el modo de relacionamiento entablado con el incario, donde hemos empezado a considerar la posibilidad de que los distintos sitios de los Bañados de Añatuya pudieran responder a funciones específicas, como el hilado y aun la producción de torteros en Sequía Vieja y la talla de hueso en Laguna Muyoj, para usar localmente pero quizás también para distribuir en centros incaicos del NOA donde pudieron darse concentraciones de población -local o no- en pos del desarrollo especializado y en cantidad de ciertos productos (Angiorama y Taboada, 2016). Diversos análisis en curso apuntan a afinar esta hipótesis, entre ellos, de contextos prehispánicos finales del sitio y estudios funcionales del instrumental en cuestión.

Como síntesis, sobre el algodón podemos señalar que está registrado su hilado y tejido en tiempos coloniales, tanto para el Salado como para el oeste santiagueńo, y su cultivo al menos en algunos sectores del territorio santiagueño, y que la posibilidad de un usufructo prehispánico tardío en la zona puede seguir siendo mantenida como hipótesis probable, sobre todo si consideramos los hallazgos y fechados generados por los estudios propios. Sobre la cronología y empleo de las grandes cantidades de torteros tardíos, sigue siendo sostenible que al menos parte de ellos remitan a momentos prehispánicos y se usaran para hilar algodón.

\section{Sobre contextos y tiempos}

Si nos enfocamos ahora en los contextos de recuperación de los pocos tejidos arqueológicos publicados, hallados en la región, resulta sugerente prestar atención a que la mayor parte de estas lacónicas referencias remiten a tejidos recuperados en urnas funerarias de sitios de la llanura de clara tradición local (salvo, y a diferencia de, la urna donada por Helman Gauna). Esto nos plantea dos situaciones claves:

Por una parte, que al tratarse de urnas correspondan casi con seguridad a entierros prehispánicos (y por ende a fibras prehispánicas). Al menos es muy poco factible que la situación se diera en los pueblos de indios coloniales. Excavaciones propias (Taboada et al., 2015) y varias referencias bibliográficas nos muestran que al interior de estas reducciones los entierros se realizaban en cementerios (Reichlen, 1940; Serrano, 1940; Wagner y Wagner, 1934), de forma directa y extendida. Hasta el momento no existe registro en Santiago del Estero de urnas en cementerios coloniales, ni de ninguna urna hallada en otro contexto que contuviera algún tipo de elemento europeo que haga pensar en la perduración de esa manera de inhumar luego de la intervención española.

Por otra parte, el haber sido hallados los tejidos referidos en urnas, nos indica que se trataría de entieros secundarios (salvo quizás en el caso de infantes), cuyos tejidos podrían ser fragmentos de vestimentas perdidas en el proceso de reducción más que envoltorios o paquetes fúnebres (aunque por ahora no podemos descartar esto último). Por su parte, Reichlen (1940) menciona un caso de un conjunto de entierros primarios genuflexos donde uno de los cuerpos estaba "acompañado de fragmentos de tejido y de una pequeña vasija de cuello estrecho cubierta de pintura roja. Los otros dos cuerpos tenían la cabeza cubierta por una escudilla y cerámica polícroma 
[165]". El autor distingue esta situación de las inhumaciones coloniales referidas anteriormente. La presencia de ajuar (Angiorama y Taboada, 2016) y de cerámica polícroma -entendible como Averías- la ubicaría para momentos tardíos del período prehispánico. Si bien no sabemos qué tipo de materia prima conforma el tejido en cuestión, el caso permite ubicar como prehispánica la práctica del tejido y la del enterramiento acompañado de tejidos, no solo en urnas sino también en inhumaciones directas.

Cabe prestar atención también a los diversos tipos de tejidos hallados (en lo referido a la materia prima y al tipo de tejido en sí). Reichlen (1940) afirma que en la zona del Salado ha podido "encontrar varios fragmentos de tejido de una calidad notable; polícromos, probablemente de lana de guanaco y que serán estudiados ulteriormente de manera más especial [182]”. A continuación señala que exhumó "algunos fragmentos de hilos de hebra muy finos y redes casi enteramente descompuestos [182]". Interesa aquí la policromía textil y el uso de aparentemente dos fibras, una que asimila a guanaco (como vimos anteriormente, en principio registrado en el Salado para época prehispánica (Cione et al., 1979), y otra más fina que podría ser algodón o aun la ya mencionada seda del monte (ver nota 8; López Campeny, 2010). En esa misma contribución Reichlen (1940) menciona: "En Cayo López, he exhumado en el interior de una urna funeraria quebrada, una muestra de tejido liso y bastante tosco, que será estudiada más tarde con los otros fragmentos de tejido provenientes de la región de Icaño [216]". Lamentablemente, no hay datos posteriores sobre estos fragmentos o estudios, pero la cita amplía y afina la distribución de los registros a la zona chaqueña septentrional de Santiago y a los Bañados de Ańatuya, a la vez que nos muestra un posible tercer tipo de tejido (¿o fibra?) más tosco. Queda aquí planteada la posibilidad de que se trate de una pieza elaborada con fibras vegetales semi rígidas (bromeliáceas), inferencia que apoyamos en la presentación previa de citas. También es interesante notar que las referencias a tejidos suelen ir asociadas al registro de ajuar o acompańamiento funerario, una situación que entendemos se da recién tardíamente en la llanura de Santiago del Estero, o al menos en la zona del Salado (Angiorama y Taboada, 2016). En una ocasión, el hallazgo se halla asocia- do a cuentas de "turquesa" en una urna de Cañitas (en la zona de los Bañados de Añatuya) (Reichlen, 1940 [170]). Los minerales de cobre son materias primas ajenas a la región y parecen estar apareciendo en el registro local recién en momentos prehispánicos finales, quizás vinculados con el proceso de interacción entablado con el incario (Angiorama y Taboada, 2016).

En síntesis: la recuperación de tejidos arqueológicos en Santiago del Estero es escasa, se los ha encontrado en entierros directos prehispánicos y dentro de urnas de al menos dos tipos (la de Gauna, poco común en la región, y las señaladas por Reichlen, que asumimos estarían dentro de estilos comunes en la llanura santiagueña). Son además de diversos tipos y fibras ("polícromo", "liso", "tosco", "de calidad notable", "bellísima calidad", "muy finos", "tan fino como los andinos", "de hilos de hebra muy finos", "en lana de guanaco"), y se los halla distribuidos en puntos diversos, distantes, asociados a áreas de desarrollo diferenciado en cronología y características socioculturales, como son las sierras del oeste santiagueño, los Bañados de Añatuya y el sector norte del Chaco santiagueño.

Reichlen (1940) afirma que "Todos estos restos de tejido o de hilos [se refiere a sus hallazgos, por lo que hay que omitir el de la urna Gauna analizado por D'Harcourt] han sido encontrados en los sitios arqueológicos del tipo de Averías donde el tejido debía ser mucho más evolucionado y de uso corriente [182]". Esto concuerda con el mayor desarrollo de los torteros, en calidad y cantidad, también en relación a sitios vinculados al estilo cerámico Averías. Incluso Reichlen (1940) y Lorandi (1978) señalaron la significativa diferencia morfológica y de cantidad entre los torteros asociados a sitios tardíos del Salado con predominancia o exclusividad de cerámica Averías y los asociados a contextos con supremacía de cerámica Sunchituyoj y/o vinculados a la fase intermedia de la Tradición Chaco-Santiagueña. Lorandi (1978) señala que para la fase Las Lomas, la primera de su secuencia, no cuenta con registro de torteros, que para la siguiente, Quimili Paso, son grandes, simples, sin decoración y escasos, y que en la última, Oloma Bajada Icaño, son pequeños, incisos o en menor medida pintados y muy abundantes (Figura 7) (como es el caso de los de la mayoría de los hallados en grandes cantidades en la zona de los Bañados de 


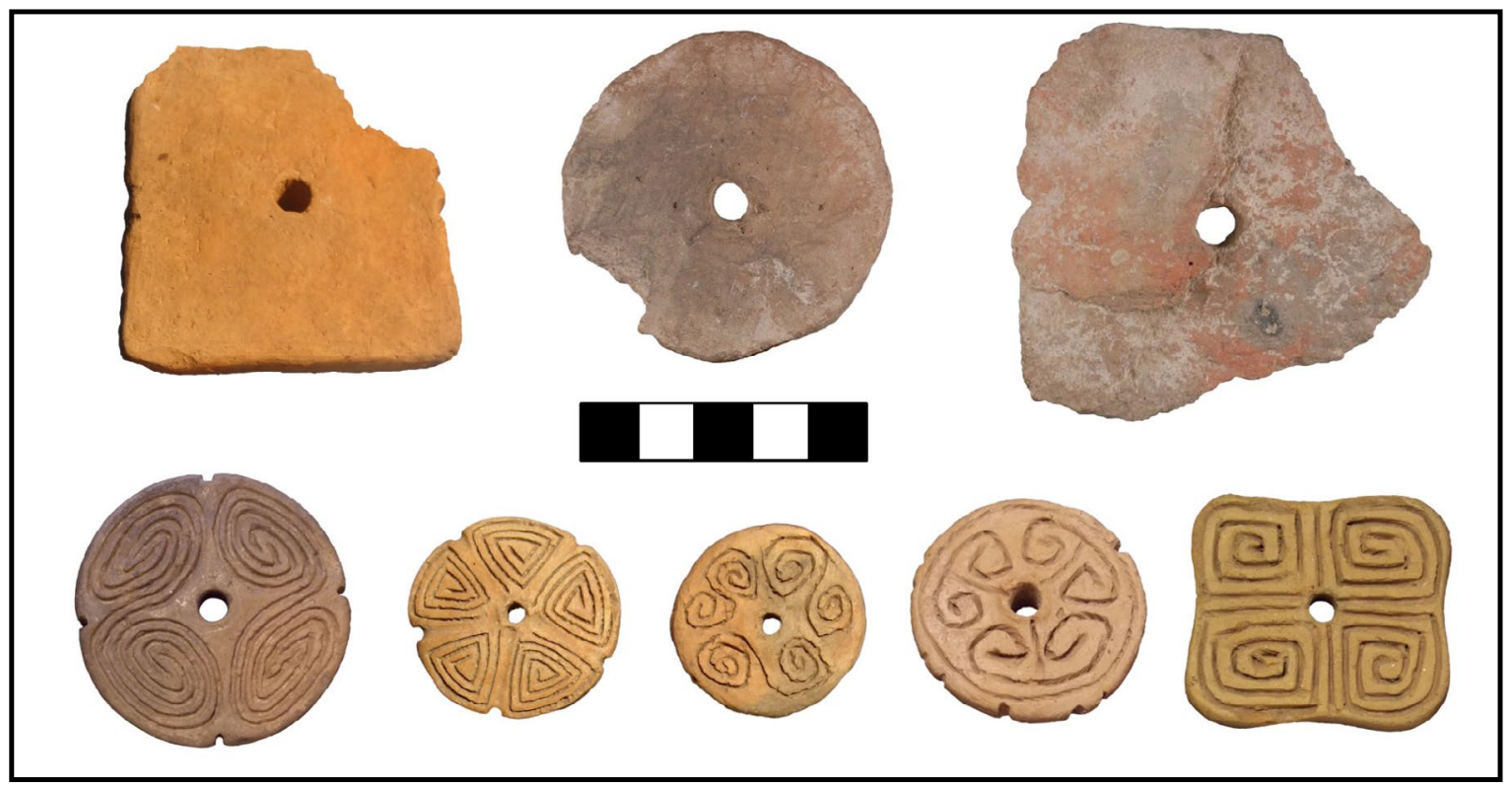

Figura 7. Fila superior: torteros de mayor peso y tamaño que aparecen en primera instancia en el registro arqueológico, en relación a la Fase Quimili Paso. Procedencia: Museo de La Plata (MLP), Depósito 25 (D25), sin N ${ }^{\circ}$, colectados por Ana María Lorandi (1967) en el sitio Icaño. Fila inferior: torteros asociados a material Averías y sitios tardíos y coloniales del Salado. Procedencia: Museo Antropológico E. y D. Wagner, Santiago del Estero; actualmente albergados en el CICPSE.

Añatuya). La pregunta simplificada es si acaso esta variación morfométrica obedece a un cambio en el tipo de fibra hilada (atendiendo así también a las referencias de Reichlen de posible "lana de guanaco"), o a un desarrollo de la tecnología textil y de las características del hilado a obtener, aunque existen también otras variables a considerar. ${ }^{30}$ Ahora bien, la aparición de torteros en un determinado momento y situación (fase Quimili Paso) apunta a que se dio alguna coyuntura que posibilitó su uso. Para esa misma fase Lorandi señala los primeros y muy esca-

30 La situación es sumamente compleja, ya que además de la dimensión temporal y la diversidad de materias primas empleadas, otra serie de factores pueden influir en la variabilidad de pesos y tamańos exhibidos por los torteros. Nos referimos a aquellos relacionados con las necesidades (o funciones, estéticas, costumbres, etc.) productivas, que determinarán el grosor y el tipo de torsión del hilado que se obtendrá, según sea la pieza, o la parte de la misma, a la que el primero esté destinado (López Campeny 2011-2012). Por ello, es común que en contextos actuales se suela emplear varios husos de diferente tamaño, con el fin de obtener hilos de diferentes grosores y para lograr distintos tipos de torsiones y/o retorsiones (Rolandi de Perrot y Jiménez de Pupareli, 1983-1985). sos registros locales de cerámica Averías (asociada a una mayoría de Sunchituyoj), situación que vincula precisamente a la emergencia textil y a la llegada de ideas o gente del actual territorio boliviano (Lorandi 1978). Para entonces se cuenta con registro de camélidos (sin identificar a nivel de especie) y se estima una posible producción de alimentos a baja escala. Así, se vislumbran dos situaciones. Por una parte, los torteros más grandes y pesados aparecen primeramente en asociación a contextos socioculturales donde hay registro de camélidos (sin determinación de especie), a situaciones que fueron interpretadas por Lorandi $(1978,2015)$ como de horticultura o agricultura incipiente de baja producción y a grupos con una aparente movilidad residencial (Taboada, 2016). Por otra parte, los torteros más pequeños y que se hallan en grandísimas cantidades en los sitios del Salado medio, aptos para el hilado del algodón, con registro de algodón asociado al menos a uno de ellos (con rango temporal pericolonial) y asociación a cerámica Averías, se vinculan a sitios con evidencias incaicas y contextos prehispánicos finales y coloniales con buen desarrollo de sistemas agrícolas. Una lectura posible es que el cambio en el tamaño y densidad de los torteros refleje un mayor desarrollo de 
la tecnología (y producción) en torno a una misma fibra. Otra lectura podría apuntar a un cambio en las mismas a partir, por ejemplo, del empleo de fibras animales en una primera instancia y del desarrollo del algodón en tiempos prehispánicos finales, en asociación al cambio operado correlativamente en otros aspectos del sistema sociocultural y a la emergencia de nuevos referentes materiales y prácticas que podrían tener que ver con la interacción entablada con grupos del oriente y altiplano sur de la actual Bolivia, que señalara Lorandi. La conclusión de Reichlen quien tuvo la oportunidad de verlos directamentesobre los tejidos tardíos asociados a sitios del Salado y a cerámica Averías sería acorde tanto a esta idea de un carácter más andino de éstos, como a una intervención inca en la producción textil (Angiorama y Taboada, 2016): "Los tejidos ejecutados por esas poblaciones precolombinas están estrechamente relacionados con los producidos por la industria textil de las regiones andinas del Nor-Oeste de la Argentina [183]".

En síntesis, la presencia de torteros a partir de aproximadamente el 1200 DC permite afirmar el desarrollo del hilado al menos desde entonces (Lorandi, 2015). Estos torteros son, sin embargo, más pesados y toscos que los que se despliegan en grandes cantidades en momentos prehispánicos finales y pericoloniales, y que López Campeny (2011-2012) calificara como aptos para el hilado del algodón. Esta situación parece indicar no solo un aumento de la escala de producción en tiempos más tardíos (Taboada y Angiorama, 2010), sino quizás también cambios en la fibra usada o en la tecnología del hilado. En tiempos más tempranos, camélidos (no sabemos si domésticos o no) identificados en el registro arqueológico pudieron quizás ofrecer fibra de poca calidad y a baja escala, relacionada con un tejido aún no muy desarrollado, vinculable a ese conjunto de torteros más tempranos y diferenciados. ${ }^{31}$ Por otro lado, aunque no es la práctica más generalizada el hilado de fibras vegetales semi rígidas ${ }^{32}$ no podemos descartar esta

31 Entre otros casos de una práctica análoga, el trabajo de Leonis Mazzanti y Puente (2015) señala el uso de lana de guanaco entre cazadores recolectores de la región pampeana y el uso de torteros para su hilado.

$32 \mathrm{Si}$ bien no suele haber un registro frecuente, Meisch (2000, citado en Guinea Bueno, 2004) menciona que las hilanderas de Molobog (Chimborazo, Ecuador) hi- opción. De igual forma tampoco se puede descartar el uso de fibras de algodón obtenidas a partir de algún sistema de producción de baja escala, aunque no contamos, por ahora, con ninguna evidencia arqueológica concreta de producción y/o recolección vegetal con fines textiles por entonces. Es decir que, la presencia de torteros en contextos que datan de alrededor de 1200 DC pone en jaque al menos alguno de los dos supuestos generales preexistentes y firmemente arraigados en cuanto al origen de las fibras textiles. Es decir, o bien se hiló fibra de camélido a pesar de no ser el ambiente propicio para la producción de una fibra de calidad (también pudo obtenerse de otros lados), o bien se hiló algodón a pesar de que las fuentes históricas parecen indicar su introducción en tiempos coloniales o incluso ausencia de cultivo local. En cuanto a las fibras vegetales semi rígidas, como antes señalamos, no suelen hilarse con empleo de huso, y en referencia a la fibra de "coyuyo" pensamos que no justificaría - por su baja densidad- un desarrollo textil en torno a un manejo exclusivo de la misma. De no ser así, la opción siempre abierta es que dichos implementos no fueran pesos de hilar. Como sea, las diferencias de tamaño y peso respecto de aquellos más tardíos no parecen ser relevantes en la definición de una morfología general funcional a esa actividad, además comprobada por el hallazgo de hilados en torno a los ejemplares de Sequía Vieja (SV150). Obviamente todo esto es una hipótesis que empezamos a desarrollar y que se irá aclarando con el avance de las investigaciones.

\section{Sobre la asociación placa-textil}

Ahora bien, la asociación placa-textil permite avanzar en la afinación de los procesos que pudieron situar estos bienes en el lugar de hallazgo. A partir de la presencia de un elevado número de piezas de metal de diseño y factura incaica y valliserrana tardía, anteriormente hemos propuesto que algunas de las mismas podían constituir "dones" que ponían de manifiesto contactos con los incas, interacción que parecía desenvolverse en torno a las poblaciones de una zona específica del Salado, justamente coincidente con aquella donde se concentra la

lan la fibra de cabuya (Furcraea andina) con un tortero bastante pesado, consistente en "un viejo aislante eléctrico redondo [77]". 
mayor densidad de torteros y metales: los Bañados de Añatuya. Se propuso que esta alta frecuencia de torteros pudiera ser el reflejo de una intensificación en la elaboración de hilados, posiblemente vinculada con una intervención estatal inca en la organización de la producción textil, la que luego pudo ser aprovechada por los europeos (Angiorama y Taboada, 2008; Taboada y Angiorama, 2010; Taboada y Farberman, 2014). Se planteó, asimismo, que la destreza local de los artesanos textiles y/o ciertas materias primas de distribución local, como el algodón o la seda del monte, podrían haber sido motivo de interés incaico (López Campeny, 20112012; Taboada et al., 2013). A su vez, la presencia de elementos típicos de la llanura en contextos incaicos de los valles parecía remitir a un contacto sostenido con los incas y con las poblaciones de los valles. En este sentido cabe destacar las similitudes que detectamos (Taboada et al., 2013) entre los torteros recuperados en sitios de la llanura santiagueńa y los procedentes de sitios ubicados en el área valliserrana del NOA (Morohuasi, Tastil, La Paya, Potrero de Chaquiago, Valle de Lerma) con cronologías tardías e incaicas.

A ello se suma que la asociación metal-textil, junto a ciertos atributos particulares de la placa circular en estudio (especialmente la presencia de los orificios próximos al borde), nos permiten plantear el muy probable uso corporal de la pieza de metal, y asumir que formó parte de la indumentaria como elemento ostensible. Desde el punto de vista teórico más general, puede ser útil enmarcar la discusión en la perspectiva del textil (y la indumentaria en general), concebido como una "poderosa piel social", con la capacidad de transmitir mensajes particulares, a través del lenguaje de los adornos corporales, a modo de una "piel superficial" de imágenes poderosas, en términos de su agencia particular (Strathern, 1979; Turner, 1980 y relecturas posteriores de Arnold, 2009; Arnold y Espejo, 2013). En este caso puntual, el exotismo de la placa para el área, sumado a su elaboración en un soporte de alta valoración, como fueron los metales en el mundo andino y chaqueño (en este caso por su rareza y dificultad de acceso), constituyen el argumento de apoyo sobre el que proponemos la hipótesis de que su uso como parte de la vestimenta, en cuanto adorno personal, podría haber sido un referente o símbolo de estatus, jerarquía, o condición particular de su portador. Lo dicho se vincula a una serie de otras observaciones realizadas en general para las piezas de metal del área y su situación en el contexto local (Angiorama y Taboada 2008; Taboada 2014, etc.). Esto sería más relevante si comprobáramos que efectivamente se trata de una tincurpa. De hecho, una serie de normativas dispuestas durante la Colonia muestran el rol clave que desempeñaba la vestimenta como símbolo de jerarquía social y de adscripción étnicacultural para los indígenas. Por una parte, sabemos que los descendientes de las familias incas del Cusco conservaron ciertos privilegios, como el uso de elementos de la indumentaria tradicional en tanto marca de su condición jerárquica. Por otra parte, la ropa era un claro indicador étnico que discriminaba a la condición indígena de la población española.

A su vez, la asociación metal-textil, y fundamentalmente el hecho de la conservación del fragmento de tela asociada, también nos permite problematizar acerca del contexto final de uso de las piezas. En este sentido, es posible que se tratara de un par de objetos que formaran parte de una indumentaria funeraria indígena, o que las piezas conformaran parte del ajuar fúnebre en términos de un objeto acompañante y no de vestimenta y adorno. Al respecto, existen referencias sobre la guarda de tincurpas envueltas en textiles a modo de paquetes ( $\mathrm{H}$. Horta com. pers. 2016). Cualquiera de los casos es relevante en el marco del conocimiento de las prácticas funerarias locales, ya que a partir del análisis de la bibliografía hipotetizamos que el acompañamiento mortuorio recién parece darse en la región en momentos prehispánicos finales y quizás en asociación al proceso de interacción inca (Angiorama y Taboada, 2016), continuando luego durante la Colonia (Taboada et al., 2015). La placa aquí analizada sería un ejemplo más de esta situación de cambio observada respecto de las prácticas funerarias locales a partir de momentos prehispánicos finales y podría vincularse al simbolismo y valor del atuendo y acceso a ciertos atributos referido anteriormente. Tal como hemos planteado en otro trabajo (Taboada, 2014), este tipo de objetos pudieron ser mantenidos en uso durante la Colonia para reforzar cierta autoridad o posición social indígena, según se ha registrado en contextos coloniales intervenidos anteriormente por el incario (Del Río, 2010). 


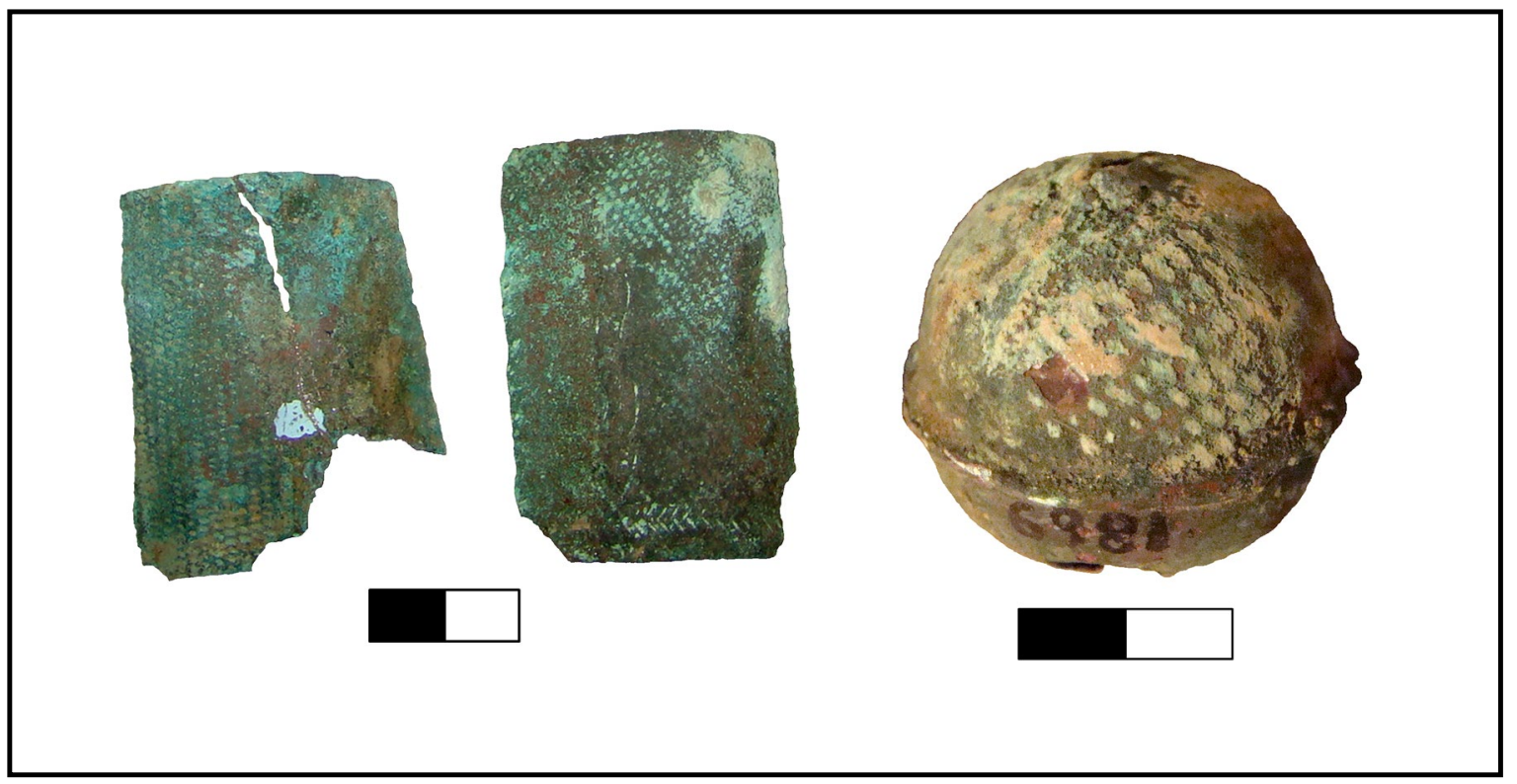

Figura 8. Ejemplos de piezas de metal que presentan pseudomorfos textiles en superficie. Izquierda: brazaletes. Derecha: cascabel. Ambos tipos de objetos pertenecientes a la colección del Museo Antropológico E. y D. Wagner de la provincia de Santiago del Estero; actualmente albergados en el CICPSE.

Por último, el conjunto de artefactos de metal que presentan pseudomorfos textiles que hemos mencionado anteriormente (Angiorama et al. 2018) indican que la asociación entre un objeto de metal y un textil (como en la situación analizada aquí) no es un caso aislado. Para estos casos es posible observar un patrón que interpretamos como producto de la presencia de estructuras de faz de urdimbre, similares a la del fragmento conservado adherido a la placa. Es decir, que se observa una disposición intercalada de los elementos de urdimbre, que serían visibles en la tela, ya que los de trama permanecían ocultos en un segundo plano y, por ende, tampoco se observan en los pseudomorfos textiles asociados a la corrosión del metal. Hemos identificado estas evidencias textiles indirectas en dos clases de piezas metálicas de las halladas en Santiago del Estero: un tipo de cascabel que en el NOA parece no ser de época prehispánica y en, al menos, cinco brazaletes (Figura 8). En ambos casos se trata de objetos que es probable que hubieran formado parte de la indumentaria (funeraria), tal como lo señala la carta de Argañaraz a Serrano arriba analizada, y que jugaran como elementos de adorno corporal y/o indicadores de estatus (Angiorama et al., 2018).
Respecto a esta asociación de los cascabeles de metal con indumentaria, puede ser útil referir el trabajo de Gentile (2012) donde, en relación a la alusión a objetos prehispánicos legados en testamentos de principios del XVII en el Tucumán colonial, se mencionan "caxcaules" asociados a "topos de plata", o alfileres para sostener el tradicional aqsu o vestimenta femenina de tradición inca [20]. Aunque las piezas de Santiago puedan remitir a una cronología o confección colonial, hay antecedentes de cascabeles prehispánicos asociados a prendas de la élite cusqueña, que además se conservaron en poder de indígenas un siglo y medio después de arribados los europeos. Formaban parte de elementos de "valor" que remiten a un pasado indígena apreciado, en tanto "marcaban" la diferenciación con el indígena común, por su asociación a la nobleza del Estado.

\section{Conclusiones}

La placa, el fragmento textil y su asociación fueron nuestro punto de partida para analizar, discutir y plantear toda una serie de aspectos vinculados al desarrollo espacial, temporal y cultural del tejido y de los objetos de metal en la región sobre los que 
venimos trabajando hace un tiempo y sobre lo que muy poco se sabía hasta entonces. Consideramos que estos planteos configuran, en sí mismos, el resultado más interesante de esta indagación, y abren una importante serie de hipótesis que habrá que ir afinando con el avance de los análisis y trabajos de campo. De hecho, el estudio del ensamble en cuestión apuntó efectivamente a buscar modos complementarios de abordar las preguntas que teníamos en juego.

En lo que respecta específicamente al conjunto analizado, podemos finalizar sintetizando algunas cuestiones. A partir de los análisis técnicos podemos afirmar que tanto la manufactura como la composición de la placa de metal responden a patrones prehispánicos comunes en el Noroeste Argentino, ajenos a la tradición de la llanura santiagueña, cuyos habitantes no desarrollaron la metalurgia. En nuestro caso, el patrón morfológico y composicional no es, de todos modos, un indicador cronológico ni cultural. Piezas metálicas similares han sido aparentemente utilizadas en tiempos preincaicos, incaicos y también coloniales. Sin embargo, como hemos dicho, el sistema de sujeción de la pieza (dos orificios pequeńos realizados a poca distancia entre sí, junto a una porción del borde) es poco común entre las placas circulares del Noroeste Argentino, y tres de las seis conocidas proceden de la llanura santiagueña, reafirmando su carácter particular en relación a esta última región. El potencial uso de la placa como parte de la indumentaria estaría indicado tanto por sus propias características formales como por la asociación con el textil. Una posibilidad es que este tipo de objeto haya sido utilizado o mantuviera su función como tincurpa, emblema usado por parte de nobles $\mathrm{y}$ funcionarios incaicos en las provincias, en fiestas y en atuendos fúnebres de las wakas (Horta, 2008) aportando a las hipótesis que manejamos sobre la interacción entablada con el Imperio (Angiorama y Taboada, 2016).

Del análisis estructural del textil podemos concluir que se trata de un tejido que no comparte atributos (dirección final de hilados) con la tradición del área nuclear inca, por lo que podríamos, en principio, desechar la posibilidad de que se trate de una pieza producida allí. Esto es significativo en el marco tanto de un posible interés inca en la producción local del algodón, como para la cuestión del usufructo del mismo en época colonial. En el estado actual del conocimiento, y en tanto no dispongamos de mayores datos sobre las tradiciones textiles de tierras bajas, solo podemos señalar que este fragmento responde a la forma tradicional de hilar en los Andes Meridionales y que ha sido confeccionado con una especie vegetal (algodón) cuyas condiciones de cultivo propicias se corresponden con las imperantes en la actual provincia de Santiago del Estero. La misma ha sido registrada en la zona al menos desde época colonial temprana y está referida en la bibliografía como posible materia prima asociada a una pieza recuperada en contextos prehispánicos locales (D’Harcourt, 1932). En cuanto a la tela, ésta se elaboró mediante el uso del telar, instrumento de origen prehispánico y conocido en el NOA por lo menos desde mediados del primer milenio de la era, aunque su uso perduró en tiempos coloniales. Por otra parte, la pieza textil muestra una cierta calidad técnica, tanto en lo que hace a la densidad de los elementos como a la regularidad de los espaciados y del grosor y tensión de torsión de hilados, lo que indicaría cierta habilidad para su manufactura. Esta calidad remite a cierta experticia y bien podría vincularse con cuestiones estéticas y/o de confort, o bien de jerarquía y culto como las señaladas arriba. Podría remitir, en consecuencia, a una prenda no ordinaria, lo que es consistente con su asociación a una placa metálica, un objeto poco común en la región. Sin embargo, la situación es compleja ya que por ahora no es posible definir una tradición textil propia de la llanura o, al menos, contar con parámetros de comparación procedentes de prendas de probada producción local. Ello se debe principalmente a las limitantes ambientales antes detalladas, lo que deriva en el hecho extremo de que, el aquí presentado, constituya el primer fragmento textil arqueológico recuperado en el área de la llanura santiagueńa que pudo ser sometido a una serie de análisis contemporáneos.

La datación obtenida permite, por su parte, contar con un primer rango cronológico de referencia, aun cuando no nos permite precisar si la confección del textil se dio en tiempos prehispánicos tardíos o coloniales. No obstante, el fechado radiocarbónico y otros datos analizados dejan abierta la posibilidad de que la placa y el textil hayan sido hallados en un contexto prehispánico. Por su parte, el hecho de 
que el conjunto en estudio esté constituido por dos tipos de bienes prehispánicos que en el Tucumán se legaban y heredaban durante época colonial (Gentile, 2012), sumado a la prohibición -formulada en las Ordenanzas de Alfaro- a los encomenderos de apropiarse de los objetos metálicos de los indígenas (Angiorama y Taboada, 2008), y al hallazgo local de piezas de metal de factura prehispánica en contextos coloniales, deja abierta la posibilidad de que la placa y el textil hayan sido depositados como acompañamiento funerario en tiempos de la Colonia. Como sea, debe quedar en claro que los dos objetos que componen la asociación en estudio remiten a prácticas de manufactura prehispánica, no hispanas; y reflejan orígenes geográficos y culturales diferenciados que confluyen en un uso final común. Mientras que la placa se vincula a un origen de la materia prima en las tierras altas y a una tradición de producción metalúrgica andina, el tejido remite a una materia prima y una producción muy posiblemente local.

Finalmente, nuestro análisis de la información disponible nos permite proponer como los lugares más probables de hallazgo del conjunto placa-textil el sitio Sequía Vieja, localizado en los Bañados de Ańatuya, o Manogasta, en las cercanías del río Dulce. En el primer caso el contexto de procedencia podría ser tanto Prehispánico Tardío como Colonial, ya que en el sitio (y también en Averías como el otro posible de la zona de los Bañados de Añatuya) se han registrado ocupaciones de ambas épocas. Tanto Sequía Vieja como Averías son además los dos sitios con mayor cantidad de evidencias incaicas o andinas. En el segundo caso, el contexto de hallazgo probable remite a tiempos coloniales. Ambas opciones son concordantes con el rango cronológico obtenido por el fechado del tejido y con los dos procesos hipotetizados de incorporación de bienes metálicos al registro local: 1. llegada del metal en tiempos incaicos, con funcionarios incaicos, o como don destinado a ciertas autoridades locales, y 2. una perduración de uso de este tipo de objetos en tiempos coloniales, que incluso incorporara cierta circulación espacial del bien. Si la placa se asocia originalmente al proceso incaico, la perduración y circulación en tiempos coloniales aportaría una explicación válida al hallazgo del conjunto en la zona del río Dulce -si fuera el caso-, un área geográfica donde hasta el momento no hay registro de otros indicadores de interacción con el Tawantinsuyu.

\section{Agradecimientos}

Agradecemos especialmente a Andrés Chazarreta y a Alejandro Yocca las autorizaciones para realizar los análisis a la placa y el textil y el estudio de los demás materiales del MCAEDW y del CICPSE. A Silvina Rodríguez Curletto, por el acondicionamiento preventivo realizado a estos materiales. A Andrés Romano, por efectuar los análisis de contenido polínico y su ayuda con el montaje y fotografía al microscopio de las fibras textiles. A Andrés Izeta, por la información brindada sobre el material perteneciente al acervo del Museo de Antropología de Córdoba. A Catriel Greco, por su asesoramiento y bibliografía para la discusión del fechado obtenido. A Judith Farberman e Isabel Castro Olańeta, por sus aportes en relación a las fuentes coloniales. A Josefina Pérez Pieroni, por realizar el abstract. A los evaluadores, por sus oportunos comentarios y sugerencias. Por supuesto, las interpretaciones vertidas son de nuestra absoluta responsabilidad. Los análisis e investigaciones fueron financiados por los proyectos PIP CONICET 11/256, PICT ANPCyT 1021y PIUNT UNT 26/G502 dirigidos por C. Taboada, J. Farberman y C. Angiorama, respectivamente.

\section{Referencias citadas}

Agüero, C. (1994). Madejas, Hilados y Pelos: Los turbantes del Formativo Temprano en Arica, Norte de Chile (Tesis de grado). Universidad de Chile, Santiago.

Agüero, C. (2010). Textiles de la región de Tarapacá durante el Periodo Intermedio Tardio. Informe de resultados FONDECYT 1030923 no publicado. Chile.

Andreoni D., Spano, R. y Lema, V. (2012). Nota sobre evidencias de uso de plantas en el sitio Soria 2 a partir del análisis microscópico del contenido de pipas. Arqueologia , 18, 235-243.

Angiorama, C., López Campeny, S. M. L. y Taboada, C. (2018). Más allá de lo evidente: análisis tecnomorfológico y composicional de piezas de metal y estructuras textiles asociadas procedentes de la llanura santiagueña (Argentina). 
Serie Monográfica y Didáctica, Vol. 56, pp. 138-143. VII Congreso Nacional de Arqueometría, Facultad de Ciencias Naturales e IML, Universidad Nacional de Tucumán.

Angiorama, C. y Taboada, C. (2008). Metales andinos en la llanura santiagueńa (Argentina). Revista Andina, 47,117-150.

Angiorama, C. y Taboada, C. (2016). Impacto, avances y estrategias heterogéneas del Tawantinsuyu en sus fines y confines. El caso de Santiago del Estero en las tierras bajas orientales de Argentina. Abstracts of the Society for American Archaeology (p. 13). 81st Annual Meeting Program. Orlando.

Arévalo y Briceño, F. (1585). Carta a un ilustrísimo obispo refiriendo todo lo que le ha ocurrido en una visita que hizo al Tucumán acerca del repartimiento y tasa de aquellos naturales. Colección Gaspar García Viñas (Biblioteca Nacional), N. 2562.

Arnold, D. (2009). Cartografías de la memoria: hacia un paradigma más viviente y dinámico del espacio. Cuadernos de la Facultad de Humanidades y Ciencias Sociales de la Universidad Nacional de Jujuy, 36, 203-244.

Arnold, D. y Espejo Ayca, E. (2013). El textil tridimensional. La naturaleza del tejido como objeto y como sujeto. La Paz: Instituto de Lengua y Cultura Aymara.

Assadourian, C. (1982). El sistema de la economia colonial. Mercado interno, regiones y espacio económico. Lima: Instituto de Estudios Peruanos.

Boman, E. (1991). Antigüedades de la región andina de la República Argentina y del desierto de Atacama. Universidad Nacional de Jujuy, San Salvador de Jujuy (Obra original 1908).

Bonetti, C. (2013). Consideraciones sobre el pasado indio en Manogasta, Santiago del Estero: una aproximación interdisciplinar al objeto de estudio. Breves Contribuciones del Instituto de Estudios Geográficos, 24, 169-192.

Carbonari, J. (1994). Asociación muestra-evento en C14. Jornadas de Arqueología e Interdisciplinas, 81-85. Programa de Estudios Prehistóricos - CONICET.

Castro Olañeta, I. (2013a). La Numeración de los indios del partido del Río Salado. Santiago del Estero, 1607. Encomiendas y servicio personal. Corpus, (3)2. Recuperado de http://corpusarchivos.revues.org/535
Castro Olañeta, I. (2013b). "Donde estan situados los mas yndios de la jurisdicción desta ciudad" Un acercamiento etnohistórico a las encomiendas y pueblos de indios del Río Salado. Santiago del Estero entre fines del siglo XVI y principios del siglo XVII. Surandino Monográfico, 3(2), 1-23. http://revistascientificas.filo.uba.ar/index.php/prohals/article/view/477/465

Castro Olañeta, I. y Carmignani, L. (2017). La Sierra de Santiago y el Valle de Catamarca a principios del siglo XVII: reflexionando sobre una nueva regionalización. Revista Prohistoria, 2, 5-22

Cione, A., Lorandi, A. M. y Tonni, E. (1979). Patrón de subsistencia y adaptación ecológica en la aldea prehispánica "El Veinte", Santiago del Estero. Relaciones de la Sociedad Argentina de Antropología, XIII, 103-116.

Corcuera, R. (2006). Mujeres de seda y tierra. Buenos Aires: Editorial Argentina.

Del Papa, L. (2012a). First approach to study the presence of domesticated camelids (Lama glama) in the ChacoSantiago region, a marginal zone of the south Central Andes. International Journal of Osteoarchaeology, 25(1), 45-60 (2015) Publicado online 15 de agosto de 2012 en Wiley Online Library (wileyonlinelibrary.com) DOI: 10.1002/oa.2262

Del Papa, L. (2012b). Una aproximación al estudio de los sistemas de subsistencias a través del análisis arqueofaunistico en un sector de la cuenca del Río Dulce y cercanias a la Sierra de Guasayán. Tesis doctoral. Facultad de Ciencias Naturales y Museo, Universidad Nacional de La Plata, La Plata.

Del Río, M. (2010). Los tesoros de los mallkus de Pocona y Totora en el siglo XVI. Chungara. Revista de Antropología Chilena, 42(1), 199-220.

D'Harcourt, R. (1932). Note sur la technique d'un tissu ancien du Chaco argentin. Journal de la Société des Américanistes, nouvelle série, tome XXIV, 189-191.

D'Harcourt, R. (1962). Textile of the ancient Peru and their techniques. Denny, G.G. y Osborne, C. M. (Eds.), traducción S. Brown. Seattle: University of Washington Press.

Doucet, G. (1986). Los réditos de Quilpo: funcionamiento de una encomienda cordobesa a fines del siglo XVI. 


\section{Jahrbuchfür Geschichte von Staat Wirtschaft und Gesells- chaft Lateinamerikas, 23, 63-119.}

Emery, I. (1966). The primary structure of fabrics. Washington: The Textile Museum.

Farberman, J. (2008). Santiago del Estero y sus pueblos de indios: De las ordenanzas de Alfaro (1612) a las guerras de independencia. Andes [online], 19, 225-250. http:// www.redalyc.org/pdf/127/12711815009.pdf

Farberman, J. y Taboada, C. (2012). Las sociedades indígenas del territorio santiagueño: apuntes iniciales desde la arqueología y la historia. Runa, 33(2), 113-132.

Farberman, J. y Boixadós, R. (2006). Sociedades indígenas y encomienda en el Tucumán colonial. Un análisis comparado de la vista de Luján de Vargas. Revista de Indias, vol. LXVI (238), 601-628.

Fernández, D. (1571). Historia del Perú, primera parte. Libro segundo. En Berberián, E. (Comp.). (1987). Crónicas del Tucumán Siglo XVI, Conquistadores de Indias I. Comechingonia, Revista de Antropología e Historia (pp. 47-63). Córdoba, Argentina.

Ferreiro, J. P. (1997). Maquijata: encomienda, tributos y sociedad en el Tucumán colonial temprano. En Lorandi, A. M. (Comp.). El Tucumán Colonialy Charcas, tomo II (pp. 73-128). Buenos Aires: Universidad de Buenos Aires.

Freyre, R. J. (1915). El Tucumán Colonial. Buenos Aires: Coni Hermanos.

Garavaglia, J. C. (1986). Los textiles de la tierra en el contexto colonial rioplatense: ¿una revolución industrial fallida? Anuario IEHS, 1, 45-87.

Garcilaso de la Vega, I. [1572] 1960. Obras completas del Inca Garcilazo de la Vega. Madrid: Atlas, Colección Biblioteca de Autores Españoles.

Gentile Lafaille, M. E. (2012). Objetos prehispánicos legados en Testamentos de Indios (Gobernación de Tucumán, 1608 y 1619). Revista Aequitas, 2, 9-43.

Gisbert, T., Arce S. y Cajías, M. (1987). Arte Textily Mundo Andino. La Paz: Editorial Gisbert y Cía. S.A.

Gómez, R. (1970). Alfarerías intrusivas de las Culturas in- digenas de Santiago del Estero. Instituto de Antropología XXXI. Córdoba: Universidad Nacional de Córdoba.

Gómez, R. (1975). Contribución al Conocimiento de las Industrias Líticas Tempranas de Santiago del Estero. Revista del Instituto de Antropología de la Universidad Nacional de Tucumán, Serie 3(2), 171-187.

González, A. R. (1992). Las placas metálicas de los Andes del Sur. Berlín: KAVA.

Gramajo, A. (1992). Pueblos de indios Postconquista de la jurisdicción de Santiago del Estero Investigación en las fuentes. Relaciones de la Sociedad Argentina de Antropologia, XVIII, 181-209.

Gramajo, A. J., y Martínez Moreno, H. (1992). Arqueología de la Subárea Guasayán. Serie Estudio, 4, 21-73.

Greco, C. (2012). Integración de datos arqueológicos, radiocarbónicos y geofísicos para la construcción de una cronología de Yocavil y alrededores (Tesis doctoral no publicada). Facultad de Filosofía y Letras, Universidad de Buenos Aires.

Guinea Bueno, M. (2004). De lo duradero a lo perecedero, II: Técnicas textiles, producción y uso del tejido prehispánico en Esmeraldas, Ecuador. Revista Española de Antropología Americana, 34, 63-84.

Hogg, A., Hua, Q., Blackwell, P., Niu, M., Buck, C., Guilderson, T., Heaton, T., Palmer, J., Reimer, P., Reimer, R., Turney, C. y Zimmerman, S. (2013). SHCal13 Southern Hemisphere Calibration, 0-50,000 Years cal BP. Radiocarbon, 55(4). DOI: 10.2458/azu_js_rc.55.16783.https:// journals.uair.arizona.edu/index.php/radiocarbon/article/view/16783

Horta, H. (2008). Insignias para la frente de los nobles incas: una aproximación etnohistórica-arqueológica al principio de la dualidad. En González Carvajal, P. y Brady, T. (Eds.). Lenguajes visuales de los Incas, pp. 71-89. Oxford: BAR International Series 1848.

Ledesma, R. (1961). Maquijata. Santiago del Estero: Instituto de Lingüística, Folklore y Arqueología, Facultad de Filosofía y Letras, Universidad Nacional de Tucumán.

Lema, V., Andreoni, D., Capparelli, A., Ortiz, G., Spano, R., Quesada, M. y Zorzi, F. (2015). Protocolos y avances en el estudio de residuos de pipas arqueológicas de 
Argentina. Aportes para el entendimiento de metodologías actuales y prácticas pasadas. Estudios Atacameños. Arqueología y Antropología Surandinas, 51, 77-97.

Lema, V. y Caparelli, A. (2007). El algodón (Gossypium sp.) en el registro arqueológico del noroeste argentino: su presencia pre y post hispánica. En Marconetto, M. B., Babot, M. P. y Oliszewski, N. (Comps.). Paleoetnobotánica del Cono Sur: Estudios de caso y propuestas metodológicas, pp. 69-78. Córdoba: Ferreyra Editores.

Leonis Mazzanti, D. y Puente, V. (2015). La producción textil como actividad doméstica de los cazadores-recolectores prehispánicos en la región pampeana, Argentina. Intersecciones en Antropología, 16(1), 131-144.

Levillier, R. (1918). Gobernación del Tucumán. Correspondencia de los cabildos en el siglo XVI. Documentos del Archivo de Indias. Madrid: Sucesores de Rivadeneyra.

Lizondo Borda, M. (1936). Documentos Coloniales. Relativos a San Miguel de Tucumán y a la Gobernación de Tucumán. Siglo XVI. Serie I, vol. I. Publicaciones de la Junta Conservadora del Archivo Histórico de Tucumán.

López Campeny, S. (2000). Tecnología, iconografía y ritual funerario. Tres dimensiones de análisis de los textiles formativos del Sitio Punta de la Peńa 9 (Antofagasta de la Sierra, Argentina). Estudios Atacameños, 20, 29-65.

López Campeny, S. (2006-2007). El poder de torcer, anudar y trenzar a través de los siglos. Textiles y ritual funerario en la Puna Meridional Argentina. Cuadernos del Instituto Nacional de Antropología y Pensamiento Latinoamericano, 21, 143-155.

López Campeny, S. (2010). Lo que el tiempo no borró... Análisis de indicadores indirectos de producción textil en Santiago del Estero. En Bárcena, J. R.y Chiavazza, H.(Eds.). Arqueología Argentina en el Bicentenario de la Revolución de Mayo, Actas del XVII Congreso Nacional de Arqueología Argentina, tomo III, pp. 1049-1054. Mendoza: Universidad Nacional de Cuyo.

López Campeny, S. (2011). La impresión es lo que cuenta... Análisis de improntas textiles. Casos arqueológicos para Santiago del Estero. Relaciones de la Sociedad Argentina de Antropología, XXXVI, 221-247.
López Campeny, S. (2011-2012). Retomando el hilo... los torteros arqueológicos de Santiago del Estero. Un giro a la discusión, primeros resultados y propuesta de investigación. Cuadernos del Instituto Nacional de Antropología y Pensamiento Latinoamericano, 23(1), 37-54.

López Campeny, S. (2014). The agency of textile technology in some archaeological ritual contexts of Northwest Argentina. Journal of Anthropology and Archaeology, vol. 2(2), 39-75. http://dx.doi.org/10.15640/jaa.v2n2a3

López Campeny, S. (2016). El textil antes del textil... Análisis de instrumental arqueológico como referente de prácticas de producción textil. Boletín del Museo Chileno de Arte Precolombino, 21(2), 119-136.

López Campeny, S. y Taboada, C. (2016). Primera evidencia arqueológica directa de hilado de algodón en Santiago del Estero (Tierras Bajas, Argentina). Temporalidades, contextos y prácticas en juego. Serie Monográfica y Didáctica vol. 54, pp. 890-893. XIX Congreso Nacional de Arqueología Argentina, San Miguel de Tucumán: Universidad Nacional de Tucumán.

López Campeny, S., Romano, A. y Guinea, V. (2017). Análisis comparativo de propiedades mecánicas de fibras naturales y tecnofacturas arqueológicas: implicancias para la interpretación de prácticas de producción textil en el pasado. Materialidades. Perspectivas actuales en cultura material, 5, 22-50.

Lorandi, A. M. (1967). Vasijas de Catamarca con caracteres excepcionales en la zona. Anales de Arqueología y Etnologia, XXII, 35-51.

Lorandi, A. M. (1978). El desarrollo cultural prehispánico en Santiago del Estero, Argentina. Journal de la Société des Américanistes, LXV, 61-85.

Lorandi, A. M. (1988). El servicio personal como agente de desestructuración en el Tucumán Colonial. Revista Andina, 11, 135-173.

Lorandi, A. M. (2015). Tukumatukuymanta. Los pueblos del búho. Santiago del Estero antes de la Conquista. Santiago del Estero: Subsecretaría de Cultura de Santiago del Estero. 
Lorandi, A. M. y Lovera, D. M. (1972). Economía y patrón de asentamiento en Santiago del Estero. Relaciones de la Sociedad Argentina de Antropología, VI, 173-191.

Mañosa, F. (2008). Relación entre las densidades de urdimbre y trama y su influencia en el aspecto superficial de los tejidos con ligamento de relieve. Boletín Intexter, 133, $55-61$.

Martínez, A., Taboada, C. y Auat, A. (2011). Los hermanos Wagner: entre ciencia, mito y poesía. Arqueología, campo arqueológico nacional y construcción de identidad en Santiago del Estero (1920-1940). Buenos Aires: Universidad Nacional de Quilmes.

Mayer, E. (1986). Vorspanische Metallwaffenund-wekzeuge in Argentinien und Chile. Munich: Verlag C. H. Beck.

Murra, J. y Morris, C. (1976). Dynastic oral tradition, administrative records and Archaeology in the Andes. World Archaeology, 7(3), 269-279.

Ortiz, G., Collantes, M., Zapatiel, J. y Burgos, M. (2016). Potenciales indicadores de usos y manejos de represas y canales antiguos en Santiago del Estero. Caso de estudio: Dos sitios cercanos al bañado de Añatuya sobre el río Salado. Serie Monográfica y Didáctica, vol. 54, pp. 2043-2047. XIX Congreso Nacional de Arqueología Argentina, San Miguel de Tucumán: Universidad Nacional de Tucumán.

Palomeque, S. (1992). Los esteros de Santiago. (Acceso a los recursos y participación mercantil. Santiago del Estero en la primera mitad del siglo XIX). Data, 2, 9-63.

Palomeque, S. (2005). Santiago del Estero y el Tucumán durante los siglos XVI y XVII. La destrucción de las tierras bajas en aras de la conquista de las tierras altas. En Palomeque, S. (Dir.), Castro Olañeta, I., Tell, S., Tedesco, E. y Crouzeilles, C. Actas del Cabildo Eclesiástico del Obispado del Tucumán con sede en Santiago del Estero. 1592-1667, pp. 45-75. Córdoba: Universidad Nacional de Córdoba y Ferreyra Editor.

Pedersen, A. (1952). Objetos de bronce de la zona del Río Salado (región Chaco-Santiagueña). Proceedings of the XXX International Congress of Americanistes, pp. 92-100.
Quispe, E., Rodríguez, T., Ińiguez, L. y Mueller, J. (2009). Producción de fibra de alpaca, llama, vicuńa y guanaco en Sudamérica. Animal Genetic Resources Information, $45,1-14$

Raffino, R. (1975). Potencial ecológico y modelos económicos en el N.O. Argentino. Relaciones de la Sociedad Argentina de Antropología, IX, 21-45.

Recopilación de Leyes de los Reynos de las Indias mandadas a imprimir y publicar por la Magestad Católica del Rey Don Carlos II, Nuestro Señor (2013). Valladolid, España: Editorial Maxtor (Obra original 1791).

Reichlen, H. (1940). Recherches archéologiques dans la province de Santiago del Estero (Rép. Argentine). Journal de la Société des Américanistes, nouvelle série, tome XXXII, 133-225.

Righetti, O. (1942). Dos conferencias sobre el imperio de las llanuras santiagueñas: "La mujer en la civilización chacosantiagueña». Buenos Aires: Compañía Impresora Argentina.

Rolandi de Perrot, D. y Jiménez de Pupareli, D. (19831985). La tejeduría tradicional de la Puna Argentino Boliviana. Cuadernos del Instituto Nacional de Antropología, $10,205-289$.

Romano, A., y López Campeny, S. (2015). Más allá del textil: abordaje profundo de las materias primas utilizadas para la elaboración de prendas arqueológicas. Serie Monográfica y Didáctica, vol. 54, p. 55. San Miguel de Tucumán: Universidad Nacional de Tucumán.

Rusconi, C. (1933). Instrumentos óseos trabajados por indígenas prehispánicos de Santiago del Estero. Revista de la Sociedad Amigos de la Arqueología, 7, 229-251.

Serrano, A. (1938). La Etnografía Antigua de Santiago del Estero y la llamada Civilización Chaco-Santiagueña. Paraná: Editores Casa Predassi.

Serrano, A. (1940). Exégesis. Relaciones de la Sociedad Argentina de Antropología II, 221-225.

Sotelo de Narváez, P. (1885). Relación de las Provincias de Tucumán. En Relaciones Geográficas de Indias. Ministerio de Fomento, tomo II. Madrid (Obra original 1582). 
Strathern, M. (1979). The Self in self-decoration. Oceania, 29, 241-257.

Taboada, C. (2011). Repensando la Arqueología de Santiago del Estero. Construcción y análisis de una problemática. Relaciones de la Sociedad Argentina de Antropología, XXXVI, 197-220.

Taboada, C. (2014). Sequía Vieja y los Bañados de Añatuya en Santiago del Estero. Nodo de desarrollo local e interacción macrorregional. Comechingonia, 18, 93-116.

Taboada, C. (2016). Montículos arqueológicos, actividades y modos de habitar. Vivienda y uso del espacio doméstico en Santiago del Estero (tierras bajas de Argentina). Arqueología de la Arquitectura 13. DOI: http://dx.doi. org/10.3989/arq.arqt.2016.003

Taboada, C., y Angiorama, C. (2010). Metales, textilería y cerámica. Tres líneas de análisis para pensar una vinculación entre los habitantes de la llanura santiagueńa y el Tawantinsuyu. Memoria Americana, 18(1), 11-41.

Taboada, C., Angiorama, C., Leiton D. y López Campeny, S. (2013). En la llanura y los valles... Relaciones entre poblaciones de las tierras bajas santiagueñas y el estado inca: materialidades, elecciones y repercusiones. Intersecciones, 14, 137-156.

Taboada, C., y Farberman, J. (2014). Asentamientos prehispánicos y pueblos de indios coloniales sobre el río Salado (Santiago del Estero, Argentina). Miradas dialogadas entre la Arqueología y la Historia. Revista de Arqueología Histórica Argentina y Latinoamericana, 8(1), 7-44.

Taboada, C. y Farberman, J. (2018). Interpretación interdisciplinaria para el sitio arqueológico Sequía Vieja en los Bańados de Ańatuya y el pueblo de indios y curato de Lasco (Santiago del Estero, Argentina). En Muñoz, M. (Ed.). Interpretando huellas. Arqueología, Etnohistoria y Etnografía de los Andes y sus Tierras Bajas, pp. 15-32. Cochabamba: UNIAM-UMSS.

Taboada, C. y López Campeny, S. (2009). Hilando fino: la problemática arqueológica de la producción textil en Santiago del Estero. Resúmenes de la XXIII Reunión Anual del Comité Nacional de Conservación Textil. San Miguel de Tucumán, Tucumán, s.p.
Taboada, C., Rodríguez Curletto, S., Ortiz, G., Pérez Pieroni J., Barazzutti, M., Bertelli, A., Domínguez, M., Finetti, F., Juárez, C., Savino, S. y Medina Chueca, J. (2015). Reutilización del espacio y diversidad de prácticas inhumatorias postcontacto en el sitio Sequía Vieja (Santiago del Estero). Resúmenes del VI Congreso Nacional de Arqueología Histórica. Universidad Nacional de Cuyo. Editado en CD.

Togo, J. (2004). Arqueología Santiagueńa: Estado actual del Conocimiento y Evaluación de un Sector de la Cuenca del Río Dulce (Tesis doctoral no publicada). Facultad de Ciencias Naturales y Museo, Universidad Nacional de La Plata, La Plata.

Turner, T. (1980). The social skin. En Cherfas, J. y Lewin, R. (Eds.). Not Work Alone, pp. 112-140. Beverly Hills: Temple Smith.

Ventura, B. y Scambato, A. C. (2013). La metalurgia de los valles orientales del norte de Salta, Argentina. Boletín del Museo Chileno de Arte Precolombino,18(1), 85-106.DOI :10.4067/S0718-68942013000100006

Vitry, C. (s/f.) La momia del cerro Chuscha. Museo de Antropología de Salta. Recuperado de: http://www.antropologico.gov.ar/chuscha.htm

Wagner, E. y Wagner, D. (1934). La Civilización ChacoSantiagueña y sus correlaciones con las del Viejo y Nuevo Mundo. Tomo I. Buenos Aires: Compañía Impresora Argentina S.A.

Wagner, E. y Righetti, O. (1946). Archéologie Comparée. Résume de Préhistoire. Buenos Aires: Edición de autor. 
